\title{
Regionalization Of Java Island: Poverty, Pandemic and Gender
}

\author{
Estuning Tyas Wulan Mei ${ }^{{ }^{*}(\mathbb{D})}$, Lutfi Mutaali ${ }^{1}$, Muhammad Baiquni' ${ }^{1}$, Rijanta1 ${ }^{1}$, Bambang \\ Sri Eko Prakoso1, Joko Christanto', Dodi Widiyanto', Alia Fajarwati ${ }^{1}$, Surani Hasanati ${ }^{1}$, \\ Agung Satriyo Nugroho', Idea Wening Nurani', Rizki Adriadi Ghiffari ${ }^{2}{ }^{\mathbb{D}}$, Didik Sri \\ Wahyudi', Adji Saiddinullah2, Muhammad Galang Ramadhan Al Tumus', Dhia Fauzia \\ Rahman $^{2}$
}

${ }^{1}$ Regional Dynamics Laboratory, Department of Development Geography, Faculty of Geography, Universitas Gadjah Mada

${ }^{2}$ Regional Development Study Program, Department of Development Geography, Faculty of Geography, Universitas Gadjah Mada

\section{ARTICLE INFO}

Article History:

Received: October 01, 2021

Revision: February 02, 2022

Accepted: February 02, 2022

Keywords:
Java Island
Regionalization
Poverty
COVID-19 Pandemic

Gender

Corresponding Author

E-mail: estu.mei@ugm.ac.id

\begin{abstract}
Among various issues on regional development planning in Indonesia, the vast coverage area and its regional diversity become one of main challenges. Regionalization is one of spatial techniques that can be used to facilitate regional development planning process. This study aims to analyze regionalization of Indonesia with a focus on Java Island by highlighting the main contemporary issues including poverty, COVID-19 pandemic, and gender. This paper draws the conditions of poverty, the cases of the COVID-19 pandemic and the needs of gender-based development in 119 regencies/cities on the island of Java using spatial distribution analysis. The results of the analysis show that the distribution of the percentage of the poor and the poverty line in Java forms a clustered pattern. This also happened in the case of COVID-19 where the high concentration of cases was around DKI Jakarta and DI Yogyakarta. As for the gender aspect, there is a tendency for a scattered pattern for the value of the gender development index, although there are some areas with high values (H-H quadrant) and low values (L-L quadrant). In general, the use of regional analysis may facilitate the identification of spatial phenomena, their distribution and the patterns formed, therefore it can be used for determining suitable regional policies.
\end{abstract}

\section{INTRODUCTION}

Regionalization is an academic way to classify regions through spatial limitations based on natural, social, economic, cultural, and political characteristics for certain purposes. Regionalization is not to limit the interaction of one region with another, but to contribute to the implementation of development in the social, economic, cultural, and political fields. Through regionalization, the understanding of phenomena in the region, be it resources, potential, as well as issues and problems, will be better, so that equitable development conditions will be achieved with good coordination and in accordance with regional goals and priorities. As stated by (Claval 2006), the notion of regionalization is a commonplace one.

According to (Sumaatmadja 1988), a region is an area that has certain distinctive characteristics that distinguish one region from another. The main characteristic is the existence of a certain homogeneity, both physically and non-physically (social, cultural, etc.). Regionalization is an attempt to delineate or provide a spatial boundary in an area. Regionalization contributes to help 
analyze the potential and answer the problems that occur in the region. The criteria for regionalization may include physical criteria, defined by landscapes, climate, resources, biodiversity, as well as cultural criteria which are defined by built landscapes, economic activities, language, culture, or others. In addition, there is an important strategy necessary for regional (subnational) estimates for assessing regional policies and programs (Verma et al. 2017). One of the approaches is using regional science.

Regions can be divided into several types, including homogeneous regions, functional regions and planning regions (Brown and Holmes 1971). The homogeneous region, also known as the uniform region, is static. Examples of delineation of homogeneous regions are based on uniformity of prominent features such as slopes, rainfall and land cover in protected areas and cultivated areas. The functional region or polarized region, often referred to as nodal region, is based on the idea that humans need space for their life activities and these activities will form a flow of reciprocal relationships such as transportation and communication between different places. The planning area is determined based on the planning objectives, the activities to be carried out and the desired development goals. Usually, the planning area uses the basis of administrative boundaries because the operational structure of development (data, budget, personnel, policies, etc.) is mobilized according to the administrative structure.

Moreover, in understanding a region, it can be determined based on its type (homogeneity or heterogeneity), based on its ranking or hierarchy (size, administrative function, service function, etc.), or based on categories, for example a single-topic area (i.e., geological area, rainfall, etc.), combined topics (i.e., climatic areas, consists of information including air temperature, precipitation, humidity, air pressure, wind direction, etc.), multitopic areas (i.e., agricultural areas, which is a combination of physical and socio-economic aspects), total area (i.e. administrative area) or compact area (i.e. planning area) (Brown and Holmes 1971; Nathan and McMahon 1990).

There are four types of development areas, namely: administrative areas, geoenvironmental areas, areas with problems, and areas with potential (Riddel 1985). Administrative areas are usually delineated according to administrative convenience, nodality uses downtown as an administrative center and has an important role in development from an operational perspective (data, budget, personnel, mobilized policies according to the administrative structure). Geoenvironmental regions are created to understand the performance of natural systems in development planning where humans are placed as agents of regional change that can move across borders both physically and non-physically, for example, a watershed-based ecosystem management model. Areas with problems are used to emphasize subjectivity and regional coverage based on certain problems, whether from a social, cultural, political, or other perspective, for example conflict zones in Indonesia. Areas with potential are defined with a focus on the resources owned by the region, both human, natural, and artificial resources that have not been fully utilized optimally, for example the area of biodiversity.

There are several benefits of regionalization, including: simplification of information on diversity in an area, facilitating observations of regional dynamics, and providing convenience in the regional development planning process. Indonesia is the largest archipelagic country (>7 million square kilometers) and has more than 17,000 islands. With a very large area and the diversity in it, it creates complexity in development planning. For this reason, one way to do is by regionalization to facilitate development planning in accordance with regional characteristics. The regionalization is conducted by mapping the characteristics of the regions. As stated by (Burkhard and Maes 2017), mapping is a valuable instrument for officials to recognize 
the relationships between ecosystems, society, and human well-being. Through this research, regionalization of Indonesia will begin with a focus on Java Island with various considerations: (i) Java Island is the most populous region in Indonesia (56.1 percent of Indonesia's population resides on Java Island according to the Population Census (SP) in 2020 (BPS 2021); (ii) Java Island has an area of only 6.75 percent of Indonesia's place, so the level of density is also the highest in Indonesia at 1,171 people per square kilometer (BPS 2020b); (iii) The number of poor people in Java is $14,060,800$ people or $53 \%$ of Indonesia's poor are located in Java (BPS 2020a); (iv) The complexity of the problems in Java, including the COVID-19 pandemic since March 2020 with the most recorded cases in Java, has an impact not only on the public health aspect, but also on economic and social conditions (Rahmawati et al. 2021; Sultan et al. 2021).

In term of COVID-19 pandemic aspect, regionalization is usually used to recognize the areas at greater risk of infection of COVID-19 diseases (Joshua et al. 2021), deaths due to COVID-19 (Grekousis, Wang, and Liu 2021), vulnerability of COVID-19 (Shadeed and Alawna 2021), prediction of "hot zones" of otolaryngological exposure to COVID-19 (Quereshy et al. 2020), and spatial and temporal surveillance of COVID-19 cases (Martinez-Beneito, Mateu, and BotellaRocamora 2021).

There are three aspects analyzed from Java region, namely poverty, COVID-19 conditions, and gender development. The reasons for analyzing these three aspects include that poverty is a basic and classic development issue and is getting more severe in line with the COVID-19 pandemic crisis. As a fundamental and classic issue, the issue of poverty becomes the first issue in Sustainable Development Goal 1 \# End poverty in all its forms everywhere contains seven targets with various indicators as a guide to a lower world poverty level in 2030. Despite the fact that since 2020, it is inevitable that the world's poverty level be further exacerbated due to the COVID-19 pandemic as stated by the UN that there has been an increase of 71 million people in the category of population with extreme poverty (https://sdgs.un.org/goals/goal1). This is also the case in Indonesia, as studied by (Suryahadi, Al Izzati, and Suryadarma 2020)) using a worst-case scenario analysis, when the economic growth rate drops to $3.5 \%$, the poverty rate is predicted to increase to $16.6 \%$, meaning another 19.7 million people become poor. This is proven by the number of workers who have been laid off and have lost their livelihoods due to the COVID-19 pandemic in Indonesia. Poverty is also one of the reasons why developing countries in ASEAN are unable to implement strict lockdown policies to control the spread of the virus as is done in developed countries with more qualified social protection (Djalante et al. 2020; Rijanta and Baiquni 2020). As it is confirmed by (Martin et al. 2020) that with no social security, COVID-19 may create a substantial economic distress to the system. In the case of online learning of schools, for example, the closure of schools may expand the learning disparity between children from lower-income and higher-income families (van Lancker and Parolin 2020).

The gender aspect in this study is seen from the comparison of the achievements between the female and male human development index, which is formed by three main dimensions, namely the health dimension, the knowledge dimension, and the economic dimension (Dini et al. 2020). The smaller the range of GPA values with a value of 100, it means that the development of women and men is more equal. Gender as a social construction that separates the duties and obligations between women and men is seen as an influential factor in inequality and poverty. Gender perspective is needed to bring a more inclusive development as one of parameters of social inclusiveness despite ecological and relational inclusiveness (Gupta et al. 2021). One of gender related problems due to COVID-19 is the limited access to education during the COVID-19 pandemic in Low Middle Income Countries (Jones et al. 2021). 
Another example is a substantial rise in child marriages following the COVID-19 crisis as marriage is seen as one of the ways to escape from reality, i.e., the pressure of school, home, and society (Arshad 2020; Rahiem 2021).

Reflecting on what has been said above, this study aims to regionalize the island of Java by highlighting the main contemporary issues which include aspects of poverty, the COVID-19 pandemic, gender, and its implications for regional policies.

\section{RESEARCH METHODS}

The study was conducted in all 119 regencies and cities on the island of Java which are divided into six provinces: Banten (4 regencies and 4 cities), West Java (18 regencies and 9 cities), DKI Jakarta (1 regency and 5 cities), Central Java (29 regencies and 6 cities), East Java (29 regencies and 9 cities), and the Special Region of Yogyakarta (4 regencies and 1 city).
This study is drawn from statistical data with regency and city analysis units sourced from Statistics Indonesia for regional poverty data in 2019 and 2020 (number, percentage of the poor, and regional poverty lines), the Ministry of Women's Empowerment and Child Protection of the Republic of Indonesia for gender data in 2019 and 2020 (gender development index), as well as sites https://covid19.go.id/,

https://kawalcovid19.id/ and provincial government websites for COVID-19 data. Research procedure is shown in Table 1.

Spatial distribution analysis using ArcGIS 10.2 software was used to determine the relationship between regencies/cities in Java, which consists of 119 regencies/cities. The Moran index as a spatial technique was used to determine the presence of spatial autocorrelation between units of analysis (regencies/cities) in Java, whether a phenomenon that occurs in the units of analysis forms a cluster or is spread out (Figure 1).

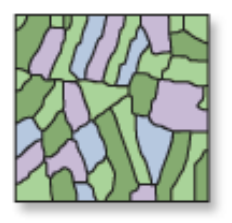

Dispersed
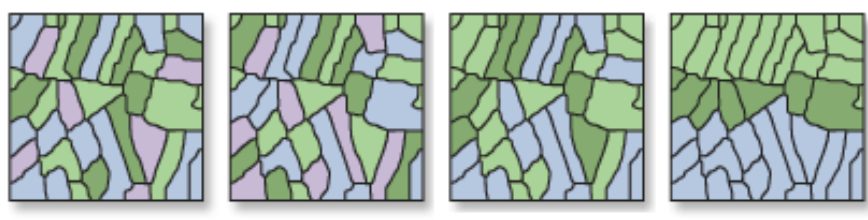

Clustered

Figure 1. Illustration of Spatial Distribution (spread out - form a cluster) (ESRI 2021a)

Moran's index was used for spatial autocorrelation analysis by calculating the difference in the value of a feature with the average value of all features and the difference between the feature values in each neighbor and the average value with the following formula (Anselin 1995; Seya 2020):

$$
I=\frac{\mathrm{N}}{\Sigma \mathrm{i} \Sigma \mathrm{j} W \mathrm{ij}} \frac{\sum \mathrm{i} \Sigma \mathrm{j} \mathrm{Wij}(x \mathrm{i}-\bar{x})(x \mathrm{j}-\bar{x})}{\sum \mathrm{i}(x \mathrm{i}-\bar{x})^{2}}
$$

$I=$ Moran Index value

$\mathrm{N}=$ number of regencies/cities

$x i=$ observation value at location $i$

$x j=$ observation value at location $j$ $\bar{x}=$ the average value of all observed variables

$\mathrm{Wij}=$ matrix element among

regencies/cities between location $i$ and location $\mathrm{j}$

The value of I will determine the pattern formed, which was divided into three patterns, namely:

- I > 0 means clustered pattern

- $\mathrm{I}<0$ means random pattern

- $\mathrm{I}=0$ means dispersed pattern (both high and low feature values are scattered in the data) 
The presence or absence of autocorrelation can be done with the following stages (Lee and Wong 2001):

- Determination of the null hypothesis (H0) and alternative hypotheses where:

$\circ$ Ho: $\mathrm{I}=0$, there is no spatial autocorrelation

○ $\mathrm{H}_{1}$ : $\mathrm{I}>0$, it means that there is a positive spatial autocorrelation

o $\mathrm{H}_{1}$ : $\mathrm{I}<0$, it means that there is a negative spatial autocorrelation

- Ho is rejected if the value of $\mathrm{Zi}>\mathrm{Za}$ or the value of $\mathrm{Zi}<-\mathrm{Za}$ so that there is a spatial autocorrelation

- Determination of the critical value, the critical $\mathrm{z}$ value is calculated by $\mathrm{a} / 2$ for $98 \%$ confidence degree

- Calculate the statistical expectation value $(\mathrm{E}(\mathrm{I}))$ with the formula:

$\mathrm{E}(\mathrm{I})=1 /(\mathrm{n}-1)$

- Calculate the value of variance with the formula:

$$
\operatorname{VAR}(I)=\frac{n^{2} S^{1}-n S^{3}+3(C)^{2}}{(C)^{2}\left(n^{2}-1\right)}
$$

Where:

$\mathrm{C}=C=\sum_{i=1}^{n} C \sum_{j=1}^{n} C i j$

$\mathrm{Cij}=$ contiguity matrix elements

$\mathrm{Ci}=$ the sum of the values of row I of the contiguity matrix

$\mathrm{Cj}=$ the sum of the values of column I of the contiguity matrix

- Calculating statistical test scores with the formula:

$$
Z(I)=\frac{I-E(I)}{\sqrt{\operatorname{VAR}(I)}}
$$

$\mathrm{I}=$ Moran Index value

$\mathrm{Z}(\mathrm{I})=$ Moran Index test statistic value

$\mathrm{E}(\mathrm{I})=$ Expected Value Moran Index

$\mathrm{VAR}=$ Variance of Moran Index
- Decision making refers to whether Ho and alternative hypotheses are accepted, with notes:

- Accept Ho if the test value is below the upper critical value

- Accept Ho if the test value is above the lower critical value

- Reject Ho if the test value is below the lower critical value

- Reject Ho if the test value is above the upper critical value

In this study, the spatial relationship used by the inverse distance method was considered the best method for the three phenomena studied (poverty, gender, and COVID-19), where the closer two features are in space, the bigger the space. the likelihood of them interacting or influencing each other (ESRI 2021b). All features can affect other features, but the farther away they are, the less impact they will have.

This study also tries to observe the distribution of the phenomena studied (poverty, gender, and COVID-19) in 119 regencies/cities which are divided into four quadrants:

- High-High (H-H) area means that regencies/cities with high observation values are surrounded by regencies/cities with high observation values.

- Low-High Region (L-H) means regencies/cities with low observation values surrounded by regencies/cities with high observation values.

- High-Low (H-L) area means that regencies/cities with high observation values are surrounded by regencies/cities with low observation values.

- Low-High Region (L-L) means regencies/cities with low observation values surrounded by regencies/cities with low observation values. 
Table 1. Research variables of the regionalization of Java Island by highlighting the main contemporary issues: the COVID-19 pandemic, gender, and its implications for regional policies.






\section{RESULTS AND DISCUSSIONS}

The results obtained in this study are the spatial distribution of the three aspects studied, namely poverty (number, percentage of the poor people, poverty line), gender (gender development index), and the incidence of COVID-19 in 119 regencies/cities on the island of Java as follows.

\section{Poverty}

There are many definitions of poverty, for example, World Bank uses an absolute definition in defining poverty. Extreme poverty is when a person lives on less than 1.9 US Dollars per day (https://www.worldbank.org/en/underst anding-poverty). Meanwhile, Statistics Indonesia defines the poor using the concept of basic needs approach. Poverty in this case is defined as the inability from an economic point of view to meet basic food and nonfood needs as measured from the expenditure side. Poor people are defined as people who have an average monthly per capita expenditure below the poverty line (https://www.bps.go.id/subject/23/kemis kinan-dan-ketimangan.html). In this study, regionalization of poverty in Java is focused on the spatial distribution of (i) the number of poor people, (ii) the percentage of poor people, and (iii) the regional poverty line in 2019 (before the COVID-19 pandemic) and 2020 (during the COVID-19 pandemic).

\section{Spatial Distribution}

The class distribution of the number of poor people in 2019 and 2020 in

Figure 2 shows an increase in the number of poor people from 395 million people to 465 million. The distribution of the percentage of poor people also increased; data in 2019 shows that the highest poverty percentage is $20.71 \%$ to $22.78 \%$ (Figure 3 ) Meanwhile, the minimum value of the poverty line in 2019 is Rp. $283,321.00$ and a maximum of Rp. 729,256.00; meanwhile, in 2020 the minimum value is Rp. 296,271.00 and a maximum of Rp. 782,731,00 (Figure 4)

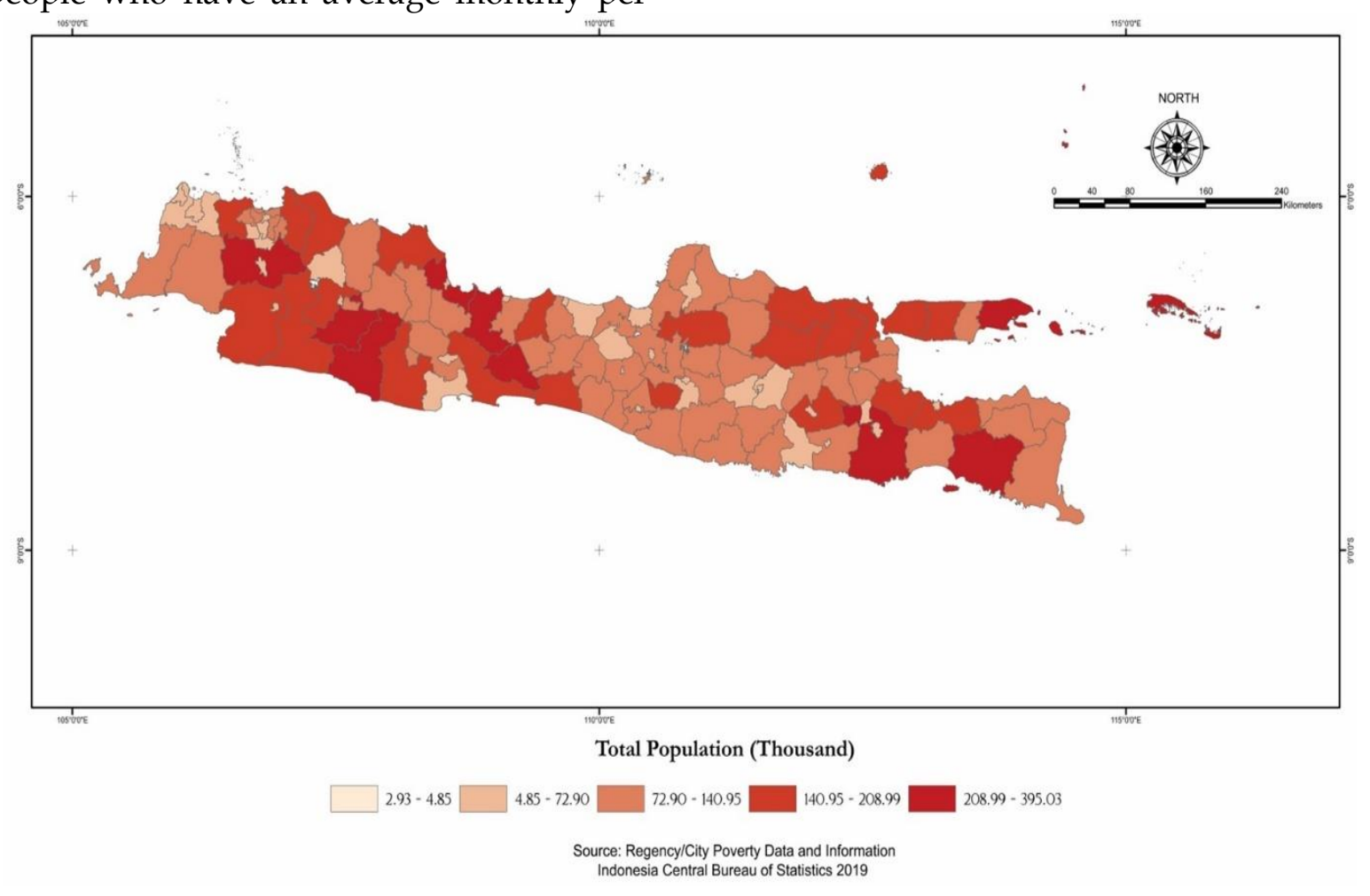




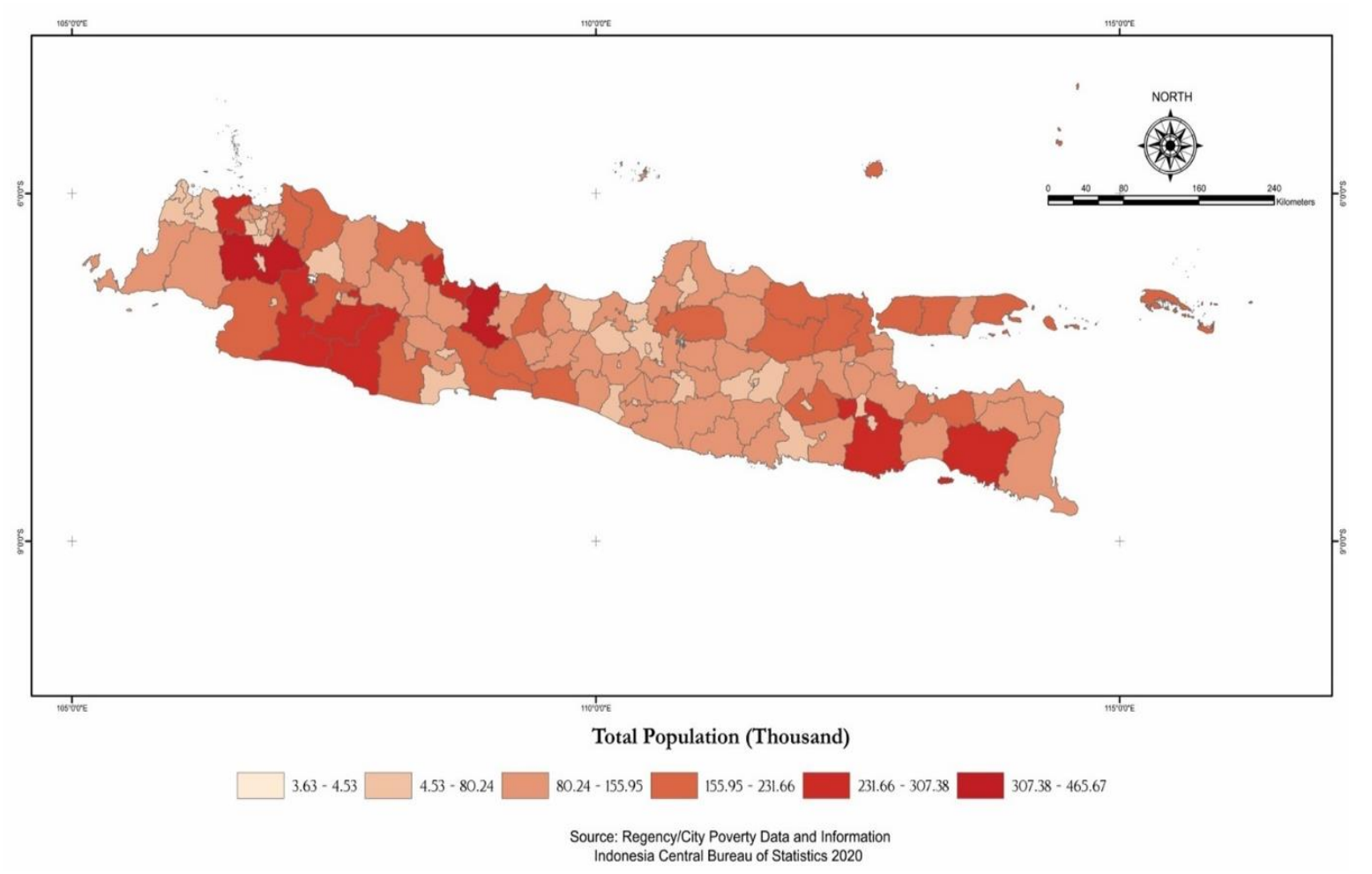

Figure 2. Distribution of the number of poor people in 2019 (top) and 2020 (bottom)

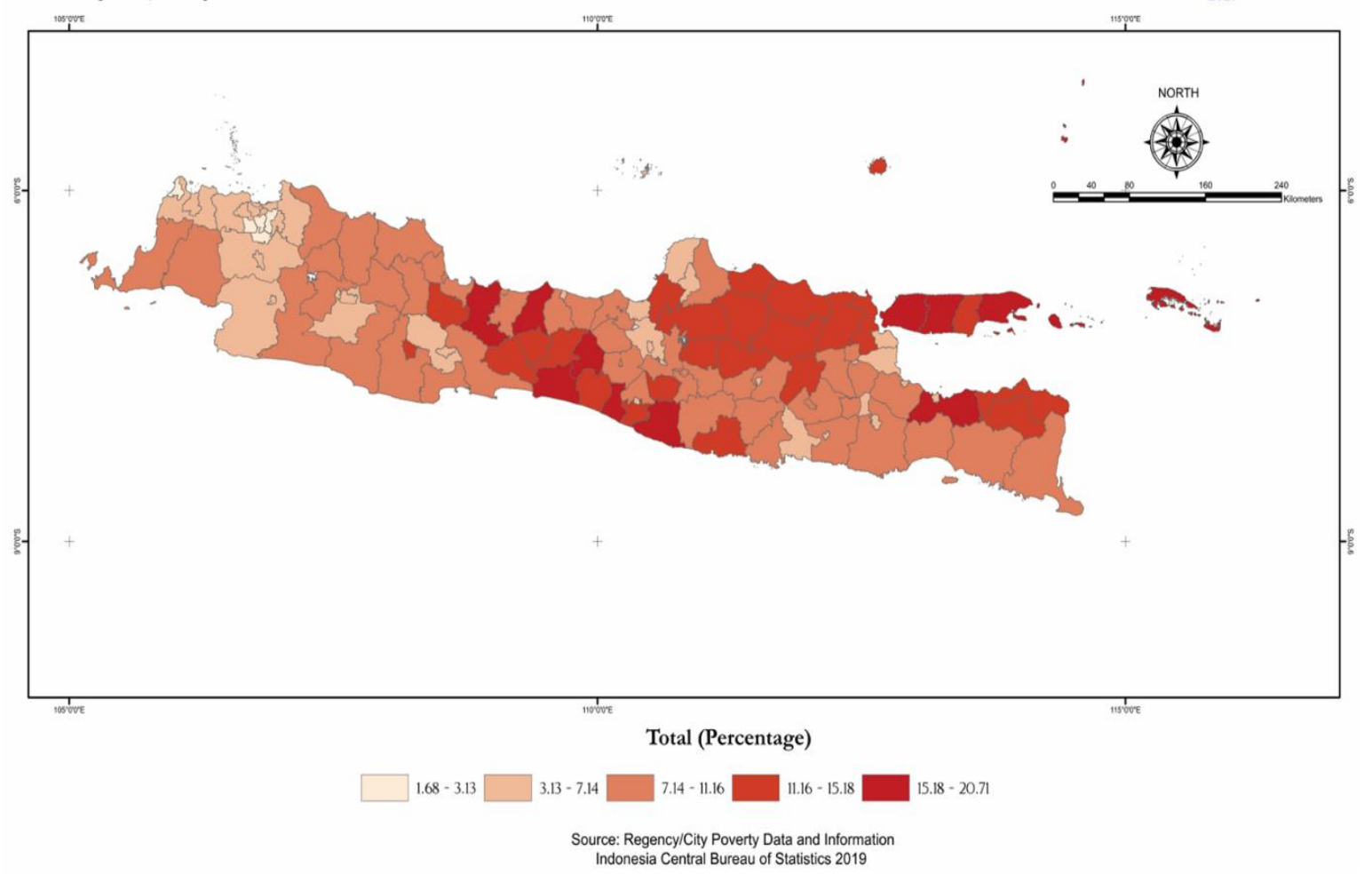




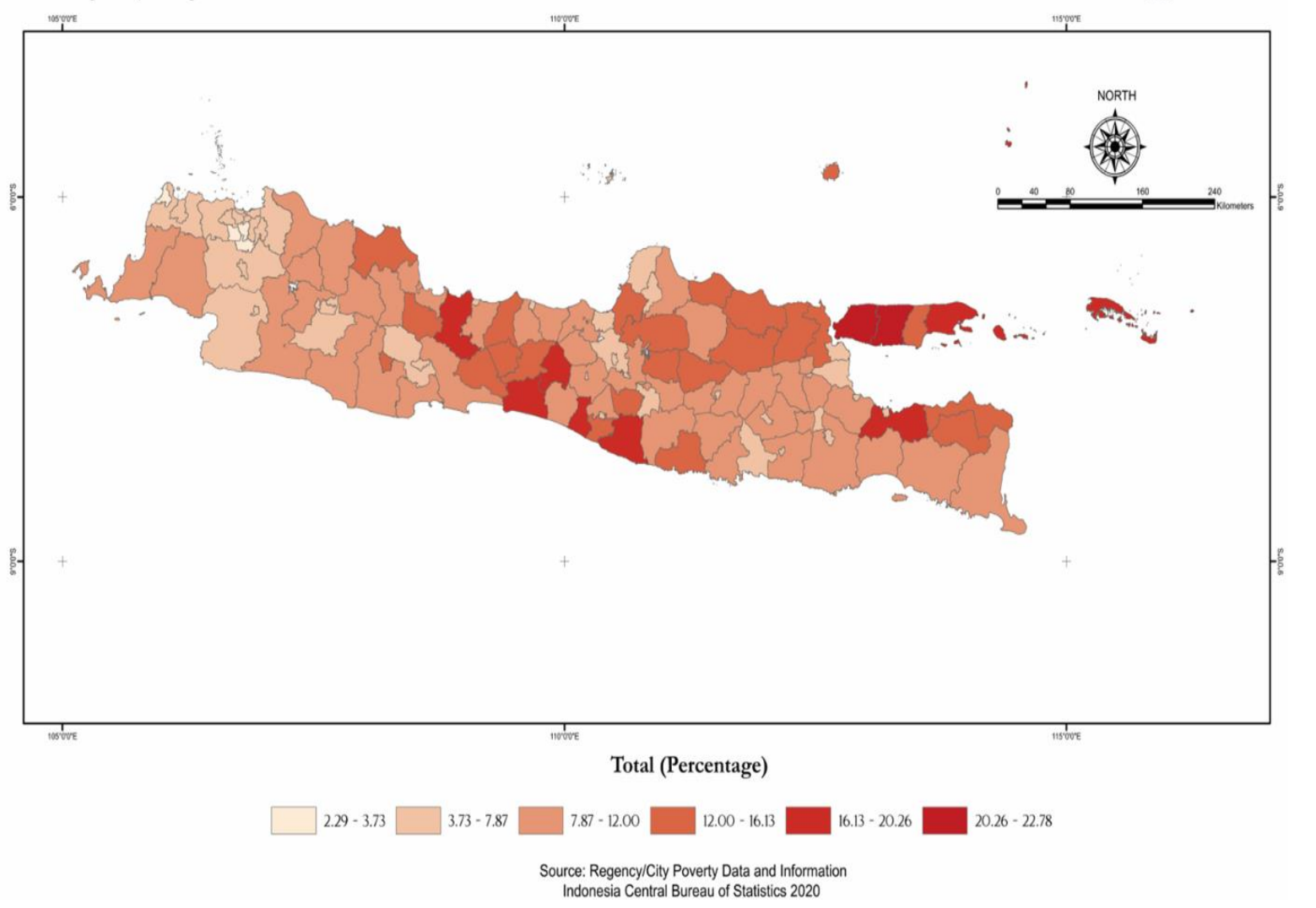

Figure 3. Distribution of the percentage of poor people in 2019 (top) and 2020 (bottom)

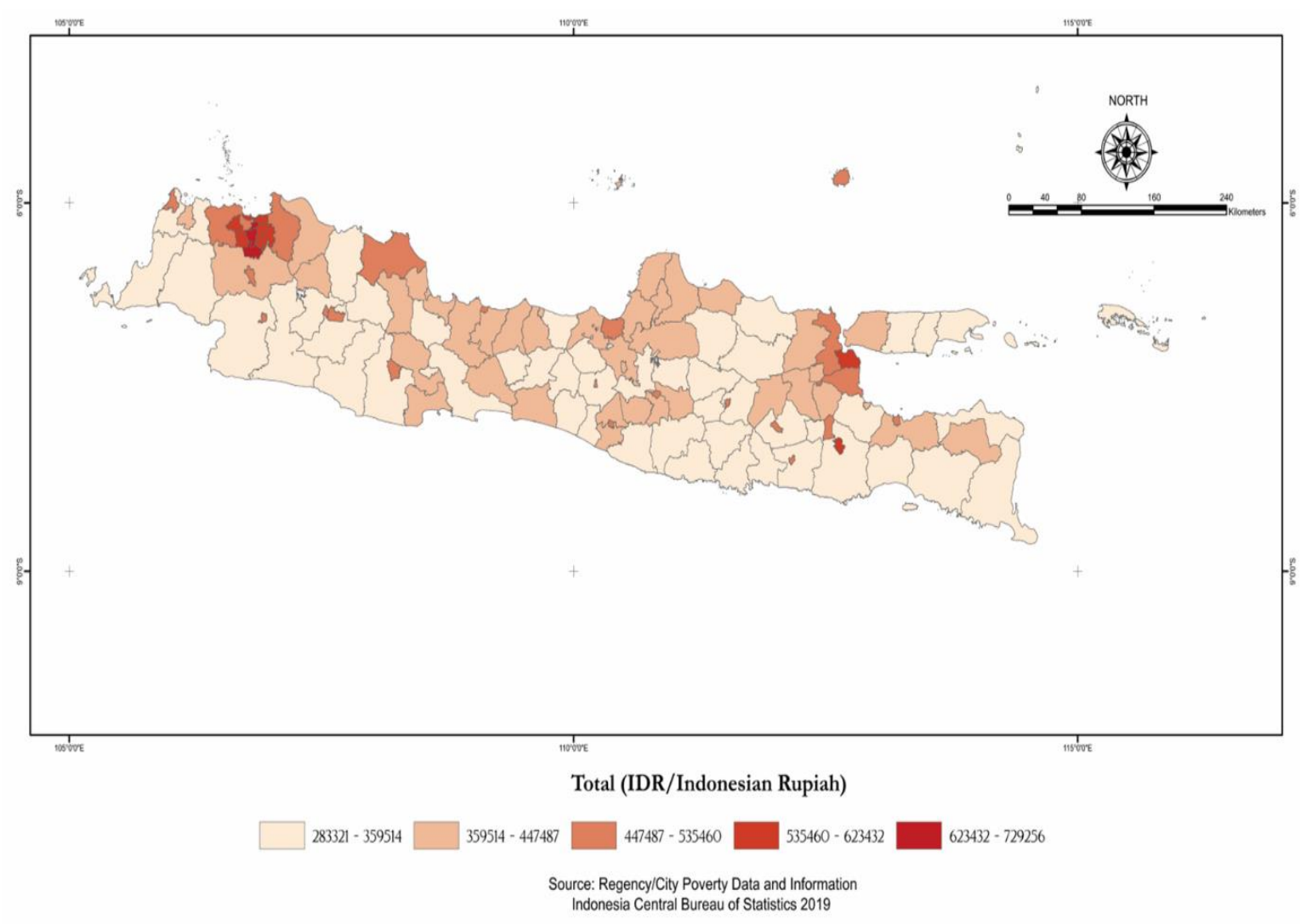




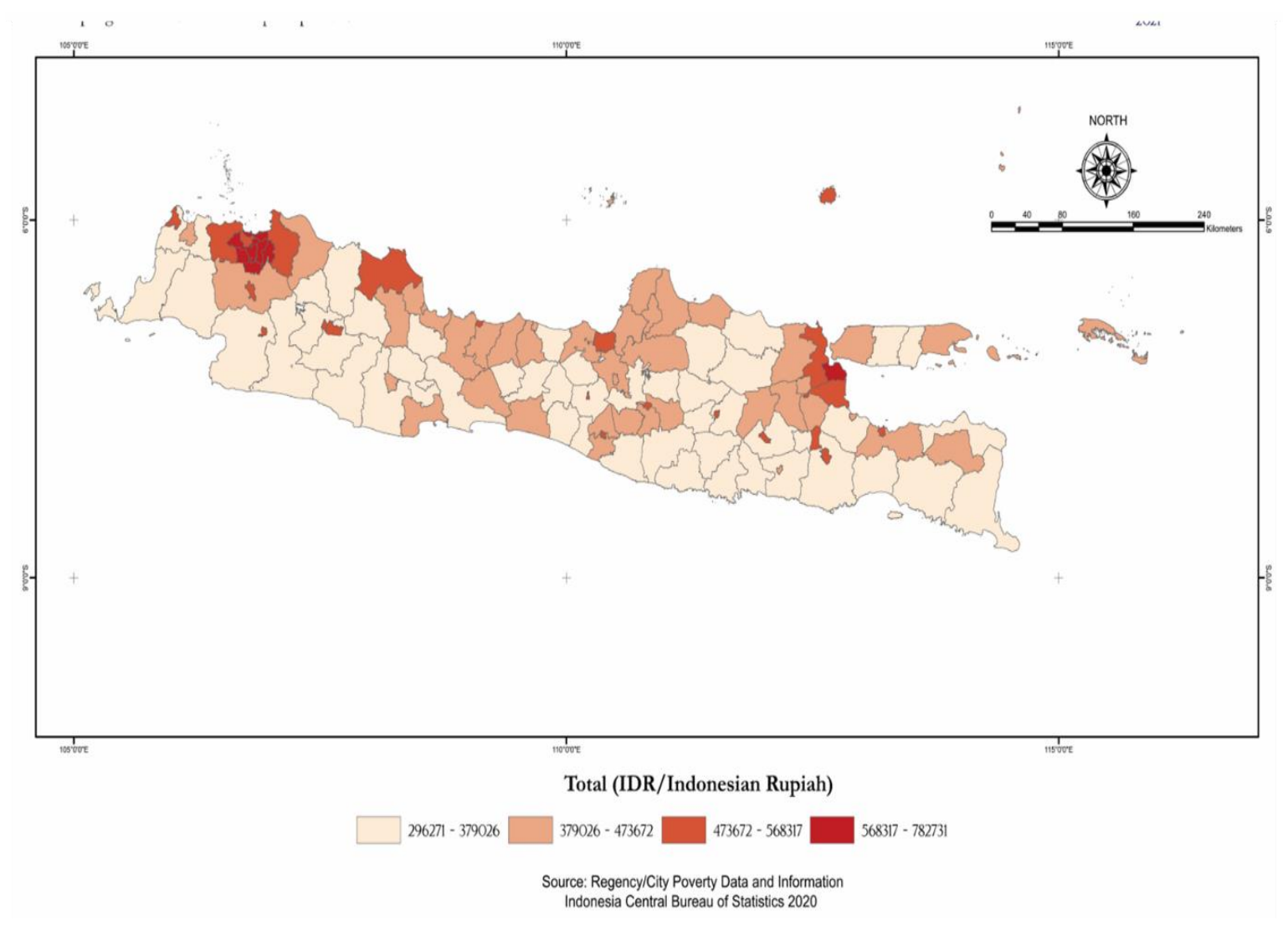

Figure 4. Distribution of the poverty line in 2019 (top) and 2020 (bottom)

\section{Distribution Pattern}

The results of research on data on the number of poor people per regency in Java in 2019 and 2020 show that the Moran Index values are -0.155862 and -0.159109 , respectively (Table 2). This value indicates that adjacent regencies/cities have varying numbers of poor people. The results of the quadrant analysis show that in the 2019 data, there are no regencies/cities with a high number of poor people surrounded by other regencies/cities with a high number of poor people. Nevertheless, the L-L quadrant for data on the number of poor people in 2019 and 2020 is mostly occupied by the same regencies/cities, including Boyolali, Wonogiri, Karanganyar, Semarang, Pacitan, Ponorogo, Trenggalek, Tulungagung, Blitar and Madiun. While the $\mathrm{H}-\mathrm{H}$ quadrant only exists in 2020 and is in Subang Regency (Figure 5).

Table 2. Global Moran I value for the distribution of the poor in 2019 and 2020

\begin{tabular}{clcc}
\hline No & & Data 2019 & Data 2020 \\
\hline 1 & Moran's Index & $-0,155862$ & $-0,159109$ \\
2 & Expected Index & $-0,008475$ & $-0,159109$ \\
3 & Variance & 0,007748 & 0,007689 \\
4 & Z-Score & $-1,674381$ & $-1,717845$ \\
5 & P-Value & 0,094056 & 0,085825 \\
\hline
\end{tabular}

Source: Research results, 2021 


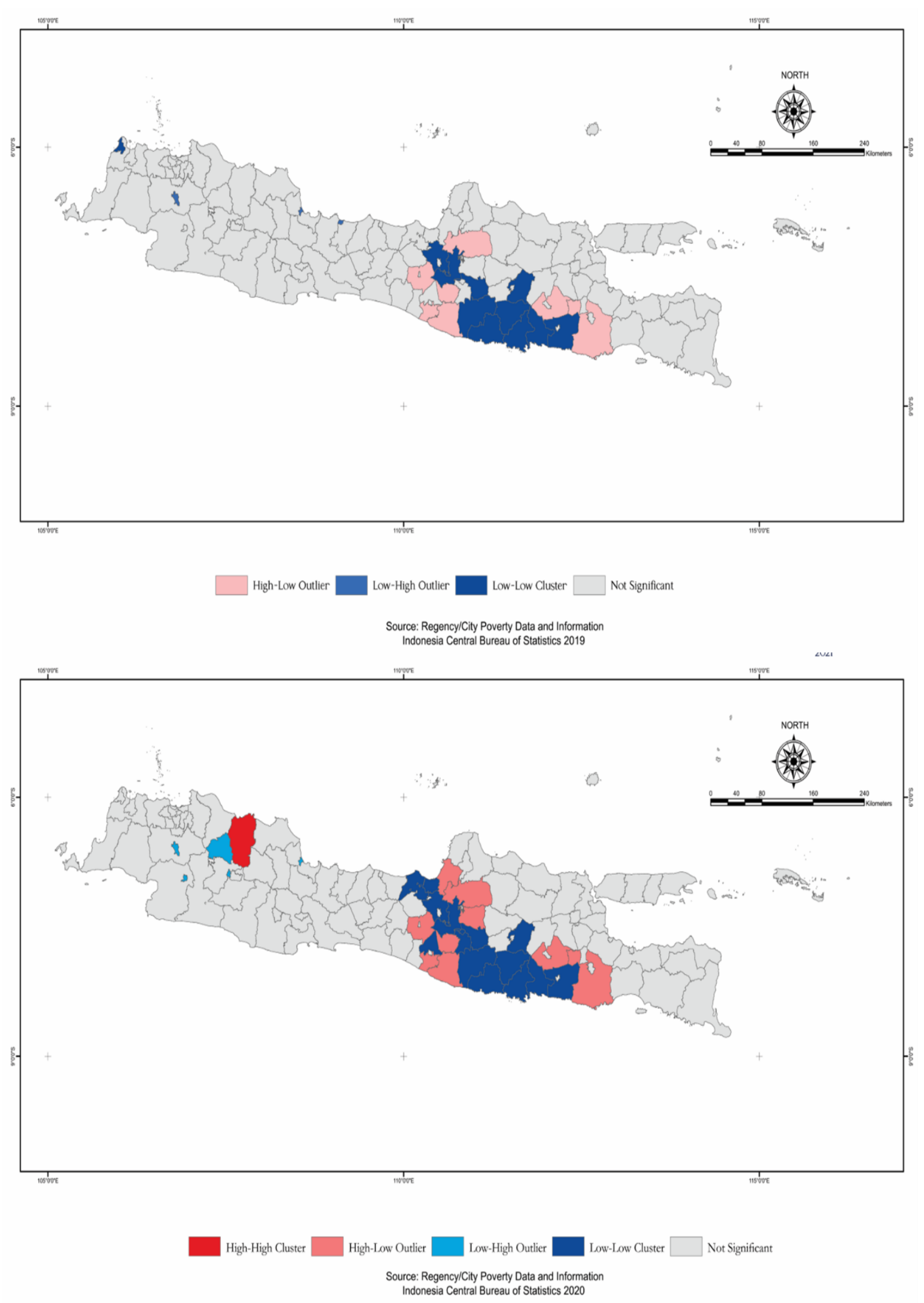

Figure 5. Distribution pattern of the number of poor people in 2019 (top) and 2020 (bottom)

For the distribution of the percentage of poor people per regency/city in Java in
2019 and 2020, it is known that the Moran Index values are 0.377850 and 0.333744 , 
respectively. This means that by regencies/cities from West Java and regencies/cities have a clustered Banten provinces as much as 25 in 2019 and distribution of the percentage of poor people (

Table 3). The results of the quadrant analysis show that there are groupings of regencies/cities that have high and low percentages of poor people. In the 2019 data, there were 11 regencies/cities included in the $\mathrm{H}-\mathrm{H}$ quadrant, while in the 2020 data there were 10 regencies/cities, the majority from Central Java Province and one regency from DKI Jakarta. The L-L quadrant is filled 23 in 2020. This quadrant shows that these regencies/cities have a low percentage of poor people and are surrounded by areas that have a low percentage of poor people. It is different if we look at the data in some regencies/cities in the southwest part of Central Java Province where there are regencies/cities with a high percentage of poor people surrounded by regencies/cities with a high percentage of poor people (Figure 6).

Table 3. Global Moran I value for the distribution of the percentage of the poor in 2019 and 2020

\begin{tabular}{llcc}
\hline No & & Data 2019 & Data 2020 \\
\hline 1 & Moran's Index & 0,377850 & 0,333744 \\
2 & Expected Index & $-0,008475$ & $-0,008475$ \\
3 & Variance & 0,007861 & 0,007852 \\
4 & Z-Score & 4,357191 & 3,861982 \\
5 & P-Value & 0,000013 & 0,000112 \\
\hline
\end{tabular}

Source: Research results, 2021

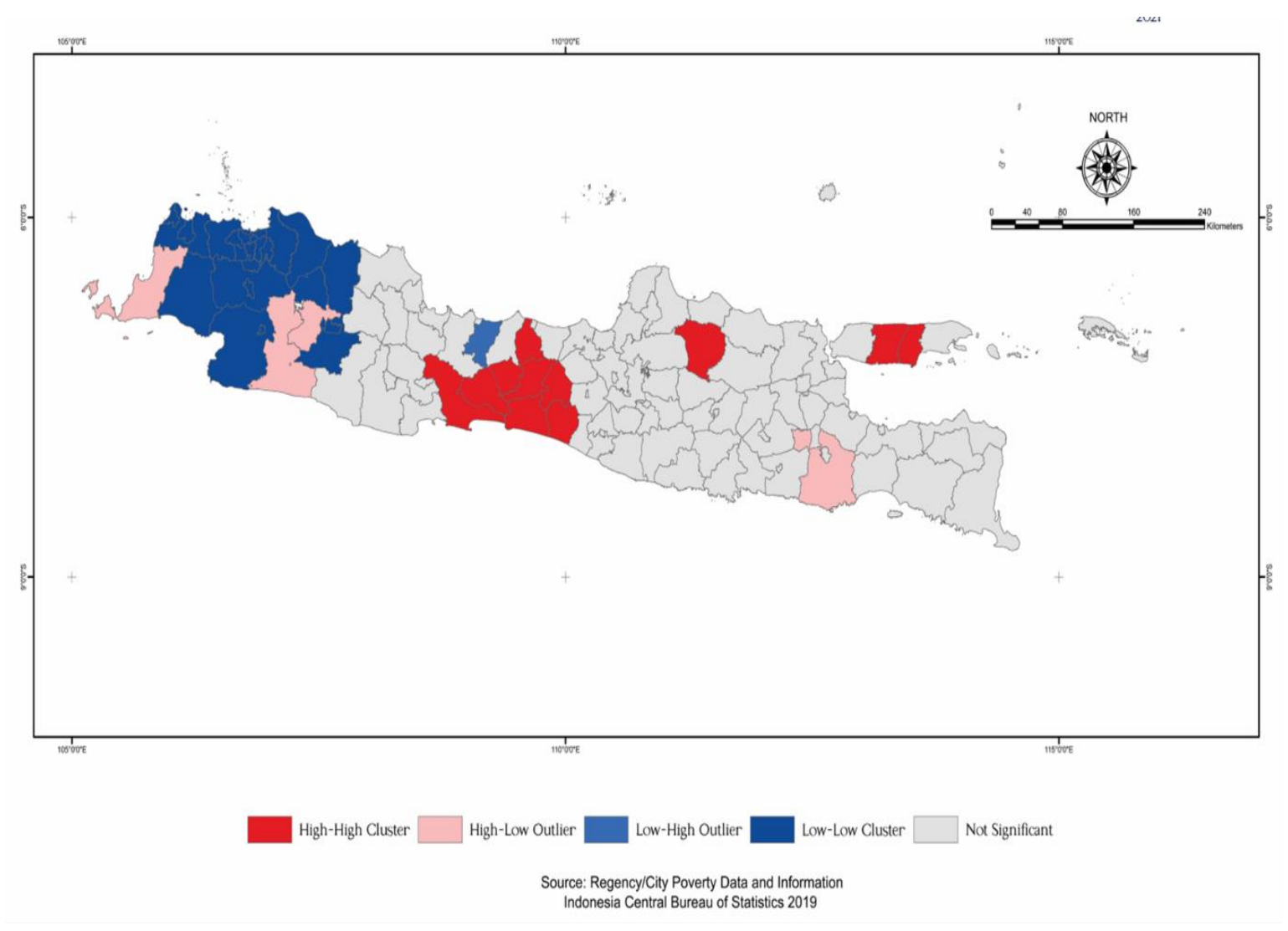




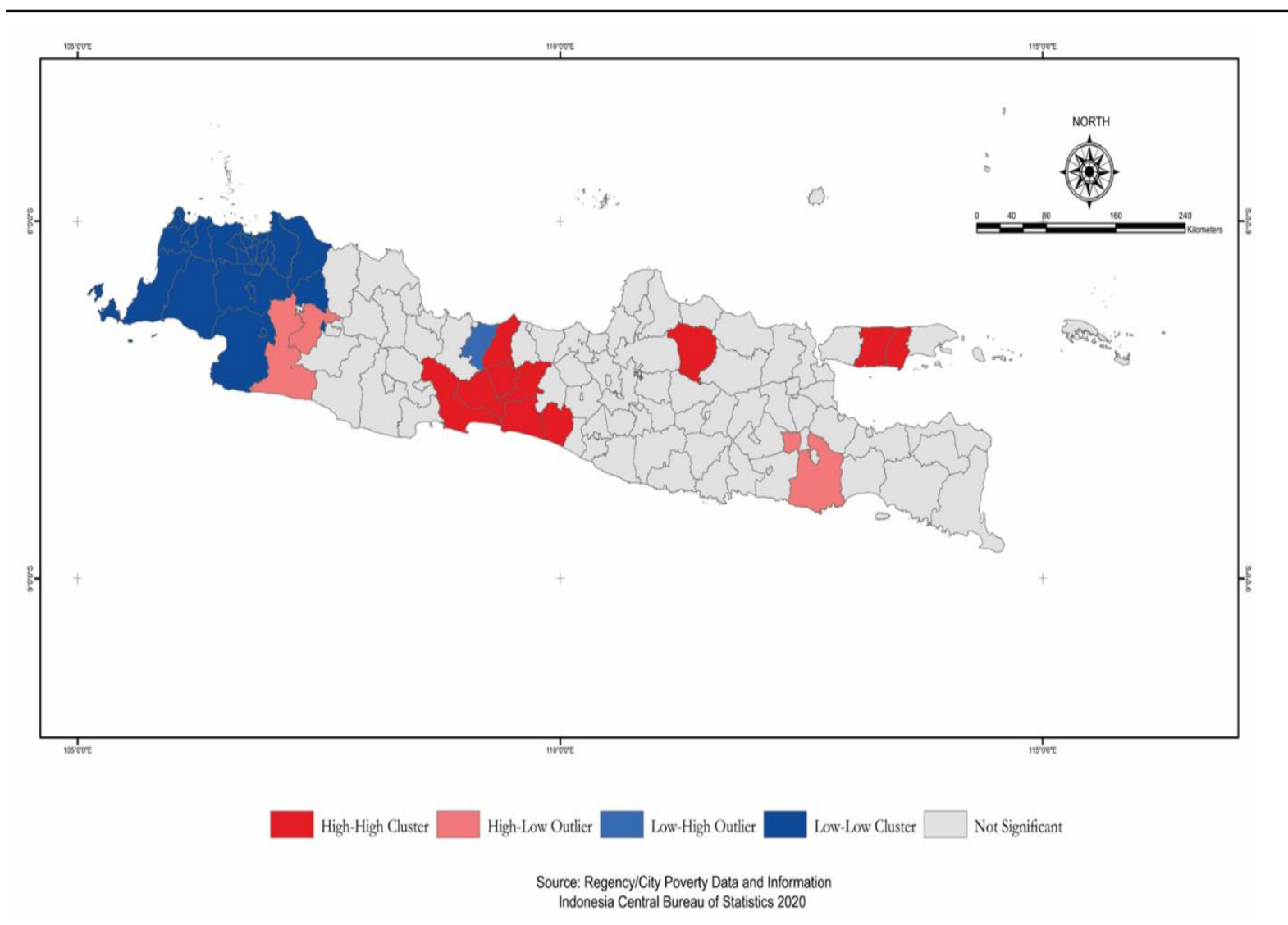

Figure 6. Distribution pattern of the percentage of poor people in 2019 (top) and 2020

(bottom)

In addition to analyzing data on the number of poor people and the percentage of poor people in regencies/cities, this study also tries to find out how the distribution of the poverty line in Java is. The results of the Moran Index value for both 2019 and 2020 data are 0.518015 and 0.567572 (Table 4). This indicates that the distribution of the regency/city poverty line is clustered. If we look further from the results of the analysis in Table 3, there is a spatial autocorrelation that occurred in 2019 and 2020. The clustering of regencies/cities with a high poverty line (HH quadrant) is concentrated in megapolitan Jakarta, which includes the Kepulauan Seribu, South Jakarta City, East Jakarta City, Central Jakarta City, West Jakarta City, North Jakarta City, Karawang, Bekasi, Bogor City, Sukabumi City, Bekasi City, Depok City, Tangerang, Tangerang City, Cilegon City, and South Tangerang City. The regencies/cities with a low poverty line (H-H quadrant) are located in parts of East Java and Central Java (Figure 7). Data for 2019 shows there are only 12 regencies/cities in Central Java and East Java, while data for 2020 shows there are 16 regencies/cities in Central Java (10), East Java (5) and West Java (1).

The issue of poverty is a basic and conventional issue in the context of sustainable development, as described in the Sustainable Development Goals, No Poverty is the first goal of the SDGs, which means showing how important this theme is in development (previously, poverty was also the main goal in the Millennium Development Goals) (https://www.un.org/sustainabledevelop ment/poverty/). Indonesia as one of the countries that participated in the success of the SDGs, also targets that by 2030 extreme poverty (income of less than 1.9 US Dollars per day) can be eradicated. The clustered spatial distribution of the percentage of poor people and the poverty line in some regencies/cities in Java can be used as a basis for determining priorities for poverty alleviation as well as reducing disparities between regions. 
Cooperation among regions is needed to find a common solution in overcoming poverty. Solidarity in economy is proven as one of the tools to alleviate poverty (Dubois 2021; Healy et al. 2021). Regional reviews through regional classification and patterns of poverty distribution are expected to identify regencies/cities with similar characteristics and through inter-regional cooperation, poverty management can be formulated in accordance with these characteristics.

Table 4. Global Moran I value for the 2019 and 2020 poverty line distribution

\begin{tabular}{llrr}
\hline No & & Data 2019 & Data 2020 \\
\hline 1 & Moran's Index & 0,518015 & 0,567572 \\
2 & Expected Index & $-0,008475$ & $-0,008475$ \\
3 & Variance & 0,007782 & 0,007769 \\
4 & Z-Score & 5,968057 & 6,535297 \\
5 & P-Value & 0,000000 & 0,000000 \\
\hline
\end{tabular}

Source: Research results, 2021

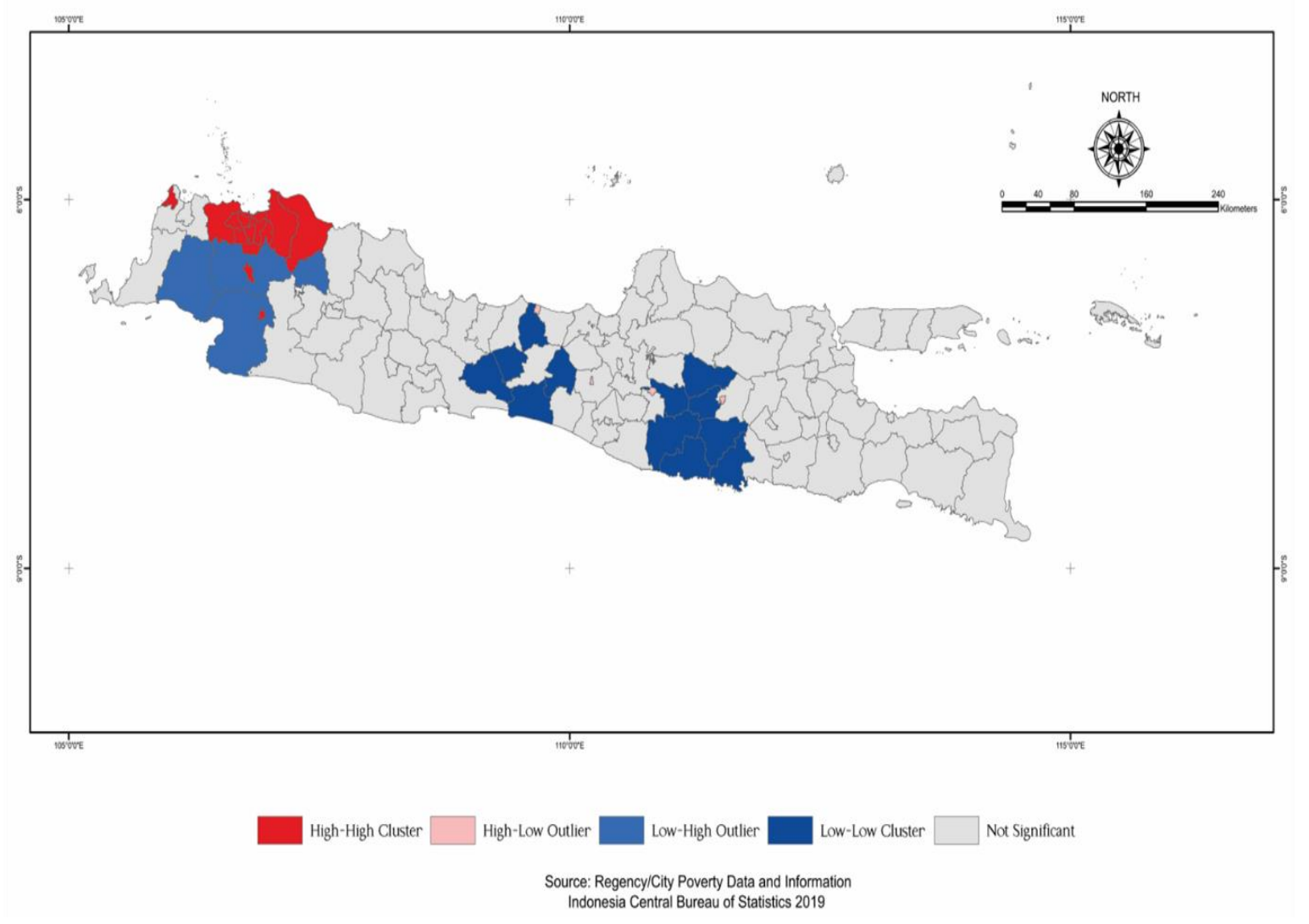




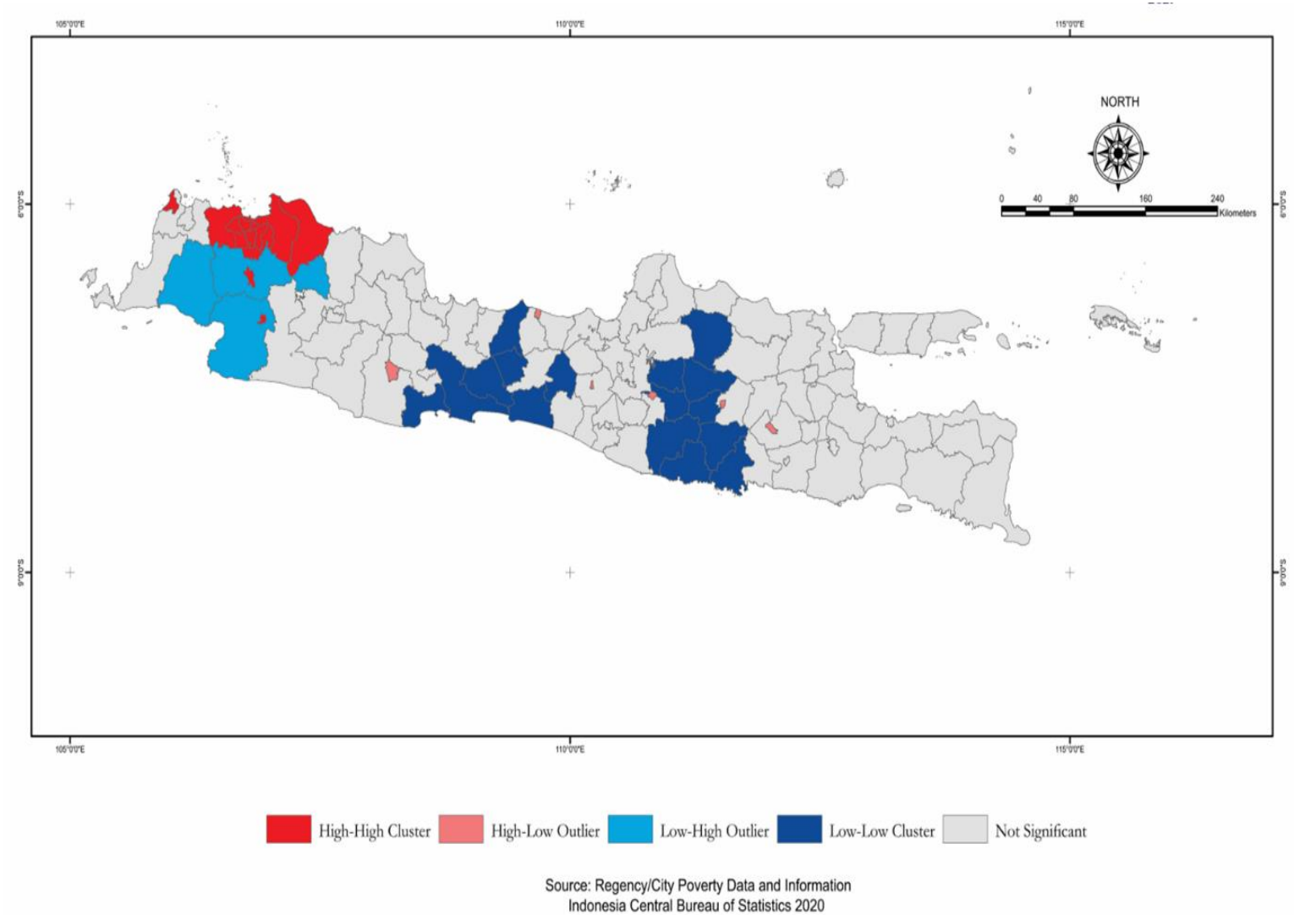

Figure 7. The distribution pattern of the poverty line in 2019 (top) and 2020 (bottom)

\section{COVID-19 case}

The first cases of COVID-19 in Indonesia, formally recorded on March 2, 2020. As for April 9, 2020, the pandemic had reached 34 provinces in Indonesia. The region with the highest number of cases is on the island of Java with DKI Jakarta, West Java and Central Java as the most exposed provinces to COVID-19 in Indonesia. The COVID-19 pandemic has not only caused fatalities and sick people, but also has an impact on the socio-economic conditions of the community, particularly related to poverty, employment, education, the economic sector (i.e., tourism) and human development in general. The vulnerable groups of the COVID-19 pandemic are not only those who are elderly, have comorbidities, but also those who have financial limitations, in addition to the limitations to deal with physical and mental crises (The Lancet 2020).
The strategy of limiting physical activity directly or indirectly hampers the economic activity of the community. In a socio-economically vulnerable environment, the policy of limiting activities can exacerbate community disparities in terms of economy, health or access to facilities and infrastructure in the region. As stated by (Wisner, Gaillard, and Kelman 2012) that marginalized and vulnerable people (economically, socially, and culturally) often also have to struggle desperately to recover after a disaster.

This study tries to see how the spread of COVID-19 cases in all regencies/cities in Java Island by focusing on secondary data analysis in July 2021 with the consideration that this period is the peak of COVID-19 cases in Indonesia, especially in Java Island, as well as regarding the availability of data, as shown in Figure 8. 


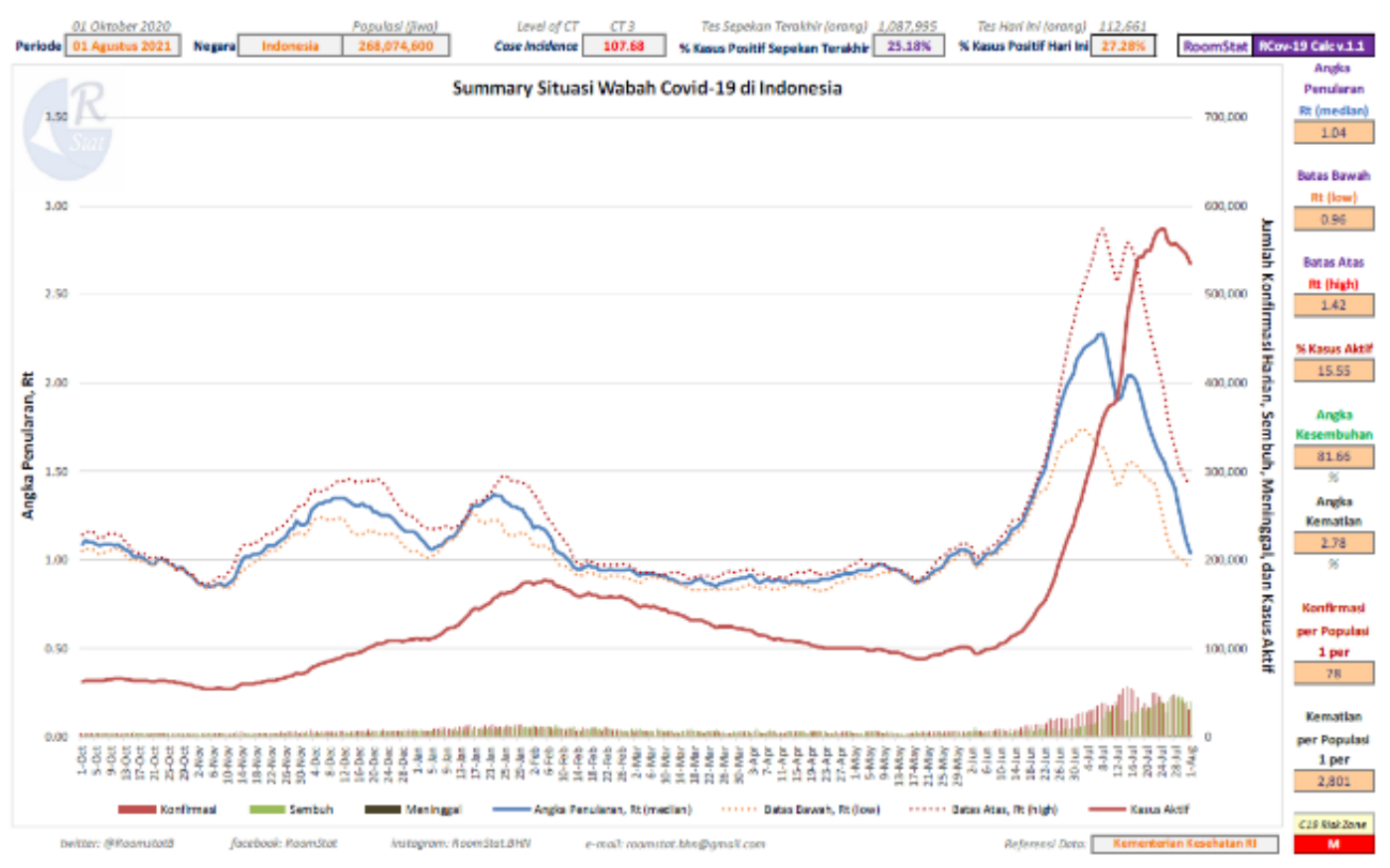

Figure 8. Trends in the development of COVID-19 cases per day (source: Twitter RoomStat.BHN https://covid19.go.id/)

\section{Spatial Distribution}

The results showed that the spatial distribution of COVID-19 cases as of 27 July 2021 was dominated by cases in regencies/cities around DKI Jakarta, DI Yogyakarta, Bandung, Surabaya, and several other big cities. This shows that the most cases of COVID-19 occur in urban areas which have a relatively higher population density than in regencies which are more dominated by rural areas (Figure 9). The use of spatial distribution analysis in the case of COVID-19 phenomena is also used in different countries: by employing spatial regression Nigeria (Bayode et al. 2022), Kazakhstan by analyzing COVID-19 hot spots and detection (Kuznetsov and Sadovskaya 2021), Romania using spatial cluster analysis (Cioban and Mare 2021), Indonesia by evaluating the COVID-19 and its relation with meteorological factors (Rendana, Idris, and Abdul Rahim 2021), and global level by analyzing the COVID-19 spatial and temporal statistics as a tool for vaccination strategy (Morais and Gomes 2021).

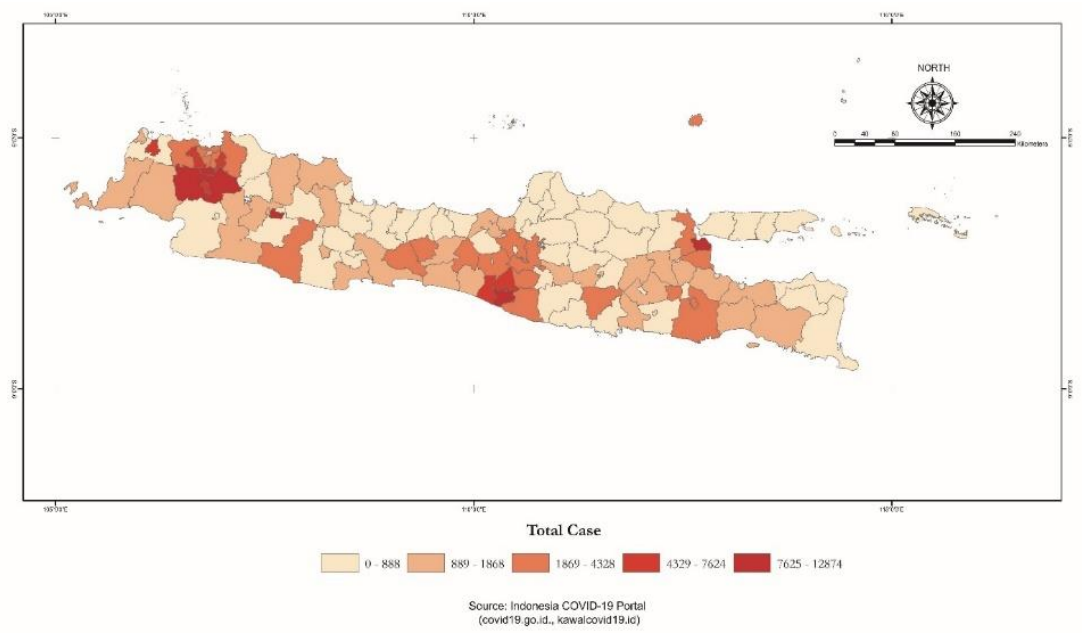

Figure 9. Spatial distribution of COVID-19 cases as of 27 July 2021 


\section{Distribution Pattern}

An interesting thing is seen in the analysis of the distribution pattern of COVID-19 cases where the Moran Index value is 0.438536 . This means that regencies/cities have a clustered distribution of COVID-19 cases (

Table 5). The results of this analysis are certainly very useful to see how the spatial distribution of COVID-19 cases is and see how the possibility of COVID-19 transmission is affected by population mobility, even though during this period the application of activity restrictions has been carried out since the beginning of the occurrence of COVID-19 cases in Indonesia, which are divided into several stages:

a. PSBB (Large-Scale Social Restrictions): 10 April - 4 June 2020

b. PSBB Transisi (Transitional Large-Scale Social Restrictions): 5 June - 10 September 2020

c. PSBB Pengetatan (Large-Scale Social Restrictions Tightening): 14 September 11 October 2020

d. PSBB Transisi (Transitional Large-Scale Social Restrictions): 12 October 2020 - 11 January 2021

e. PPKM (Enforcement of Restrictions on Community Activities) Java-Bali: 11 January - 8 February 2021

f. PPKM Berskala Mikro (Enforcement of Restrictions on Micro-Scale Community Activities): 9 February - 28 June 2021

g. PPKM Darurat (Enforcement of Restrictions on Emergency Community Activities): 3 - 25 July 2021

h. PPKM Level 4 (Enforcement of Level 4 Community Activity Restrictions): 26 July - 9 August 2021

i. PKKM Level 3-4 (Enforcement of Level 34 Community Activity Restrictions) until today
Unfortunately, although the rules for limiting activities have been in place for a long time, the high mobility of the community during the Eid al-Fitr holiday period caused a spike in COVID-19 cases from June to August 2021, known as the second wave of COVID-19 in Indonesia. Of course, the analysis of the distribution of COVID-19 cases as shown in Figure 6 is not sufficient to understand the progress and fluctuations of cases in Java, analysis with data series will be better. However, this analysis is at least able to provide an overview of the spatial distribution of COVID-19 cases during the peak period and see how the possibility of COVID-19 transmission is affected by population mobility.

It can be seen in Figure 9 that the regencies/cities around DKI Jakarta as megapolitans are included in the $\mathrm{L}-\mathrm{H}$ quadrant which means that the urban area of Jakarta is surrounded by regencies/cities with a high number of cases, but in the second layer, it is surrounded by regencies/cities with a relatively low number of cases (Figure 10). The regencies/cities included in this quadrant are Kepulauan Seribu, Central Jakarta City, Sukabumi, Cianjur, Purwakarta, Karawang, Sukabumi City, Cimahi City, Lebak and Serang.

In addition to DKI Jakarta and its surroundings, the area that is included in the $\mathrm{H}-\mathrm{H}$ quadrant is DI Yogyakarta with all its regencies/cities. In total, there are 17 regencies/cities included in the $\mathrm{H}-\mathrm{H}$ quadrant. As for the L-L quadrant, there are 18 regencies/cities spread across West Java (3), Central Java (9) and East Java (6).

Table 5. Global Moran I Value for the number of COVID-19 positive confirmed cases

\begin{tabular}{|c|c|c|c|}
\hline \multirow{2}{*}{$\begin{array}{l}\text { No } \\
1\end{array}$} & & Data COVID-19 positive confirmed cases & \\
\hline & Moran's & & 0,438536 \\
\hline & Index & & \\
\hline 2 & Expected & & $-0,008475$ \\
\hline & Index & & \\
\hline 3 & Variance & & 0,003450 \\
\hline
\end{tabular}




\begin{tabular}{lll}
4 & Z-Score & 7,610674 \\
5 & P-Value & 0,000000 \\
\hline
\end{tabular}

Source: Research results, 2021.

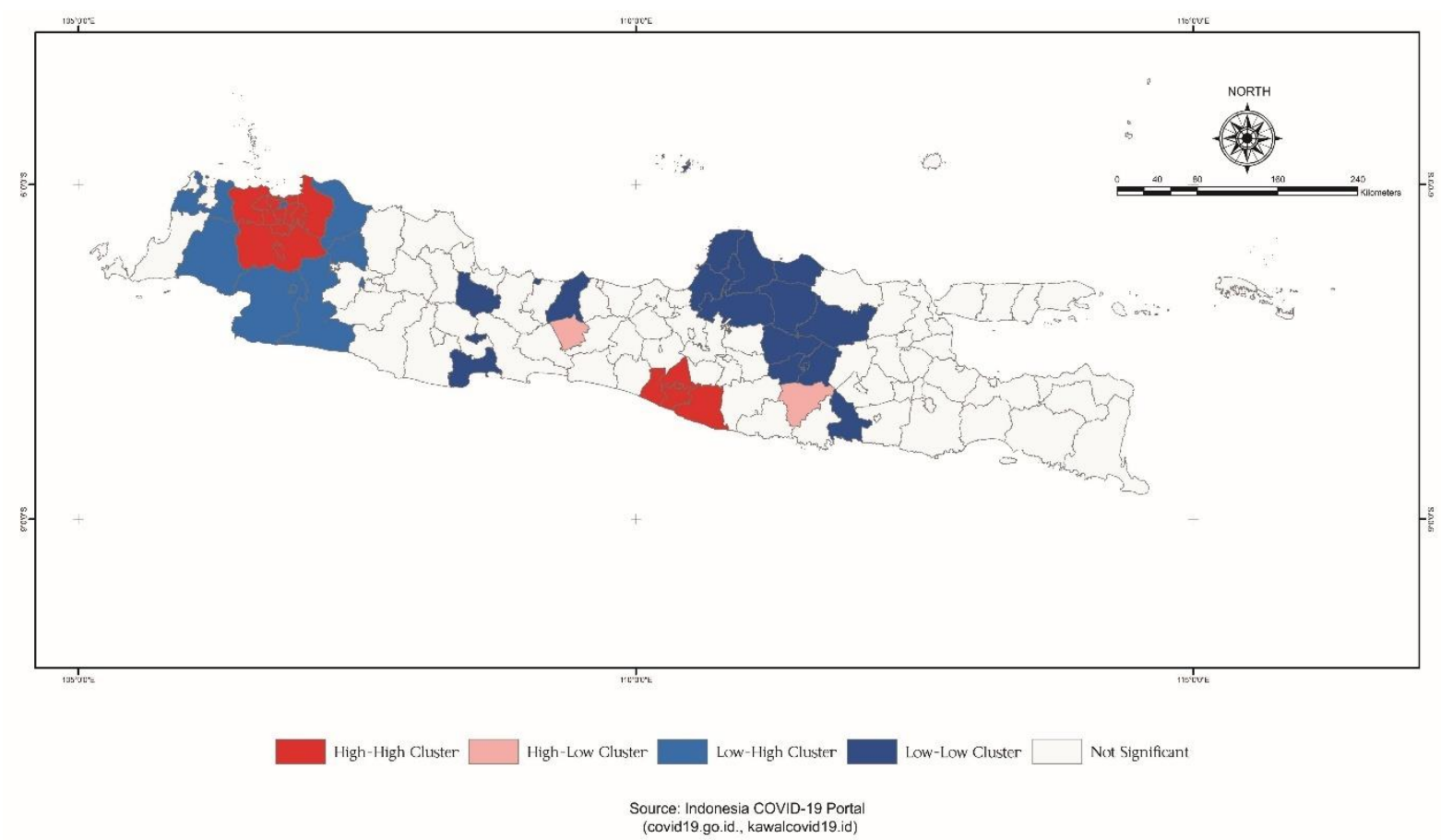

Figure 10. The pattern of distribution of COVID-19 cases as of July 27, 2021

\section{Gender}

The importance of gender issues in development has now begun to be realized and its implementation in development is continuously being pursued. This can be seen from the creation of the concept of Gender Mainstreaming which is then implemented into various aspects of development. Gender equality is also explicitly the fifth goal in the Sustainable Development Goals, namely "Achieving gender equality and empowering all women and girls".

One way of measuring gender equality is the use of the Gender Development Index. The achievement of the Gender Development Index can be used to assess the gender equality of a region because it explains the basic dimensions of development which include health, education, and decent living standards. The achievements of the Gender Development Index by the United Nations Development Program (UNDP) are classified into five classes (high, medium-high, medium, medium-low, low) based on the absolute deviation value of the male Human Development Index compared to the female Human Development Index.

The Gender Development Index (GDI) in Indonesia in 2019 was 91.07, which was still below the world average of 94.3 (UNDP 2020). According to the UNDP classification, Indonesia is generally classified as mediumhigh so it can be improved further to be included in the high classification. This increase in achievement has also been formulated in the Rencana Pembangunan Jangka Menengah Nasional (National Medium-Term Development Plan) 20202024 as one of its targets, especially to realize gender equality, namely the Indonesia's GDI can reach 91.39 in 2024.

Gender analysis is carried out by looking at the GDI value where the GDI value is close to 100, meaning that the development of women and men is increasingly equal. 


\section{Spatial Distribution}

Analysis of the spatial distribution of GDI in all regencies/cities in 2019 and 2020 shows that the GDI value close to 100 is mostly located in urban areas on the island of Java, such as DKI Jakarta, Bandung, Surabaya, Semarang, and Yogyakarta. Several other regencies/cities also have high GDI values as seen in Figure 11 which is shown in the dark red polygon. Based on Figure 11, it can be identified that areas with a high - very high GDI category form a clustered pattern in DKI Jakarta Province and its surroundings as well as parts of Central Java Province and DIY Province. The formation of this grouping can be since these areas are related in the interaction among regions that encourage development programs and have implications for human development for both men and women. If broken down, areas with high-very high GDI category in DKI Province and its surroundings are part of the JABODETABEK agglomeration. While in Central Java and Yogyakarta Provinces, these areas are the ones that have been passed by the JOGLOSEMAR agglomeration and its surroundings. In addition to the high - very high GDI category, regions in the very low - low category also form a clustered pattern in parts of West Java Province and the border between West Java Province and
Central Java Province. This grouping can be caused by the lower human development in the area, especially for the female population.

In general, the comparison of GDI maps in 2019 with 2020 does not have major changes so that the resulting spatial patterns are not different (Figure 11). However, if broken down, there are several regions that experienced changes in categories, either increasing or decreasing. Regions that experienced an increase in the category were Depok City, Demak Regency, Pekalongan City, and Kediri Regency. Meanwhile, the areas that experienced a decline were Bekasi City, Kudus Regency, Kulon Progo Regency and Pasuruan Regency. Regions that experienced an increase in the GDI category could be due to the increase in the value of male and female Human Development Index, but the increase in the female Human Development Index was greater than that of male. Meanwhile, regions experiencing a decline in the GDI category could be due to an increase in the value of the male Human Development Index which was greater than the value of the female Human Development Index, or it could also be caused by a decrease in the value of the male and female Human Development Index, as happened in Bekasi City.

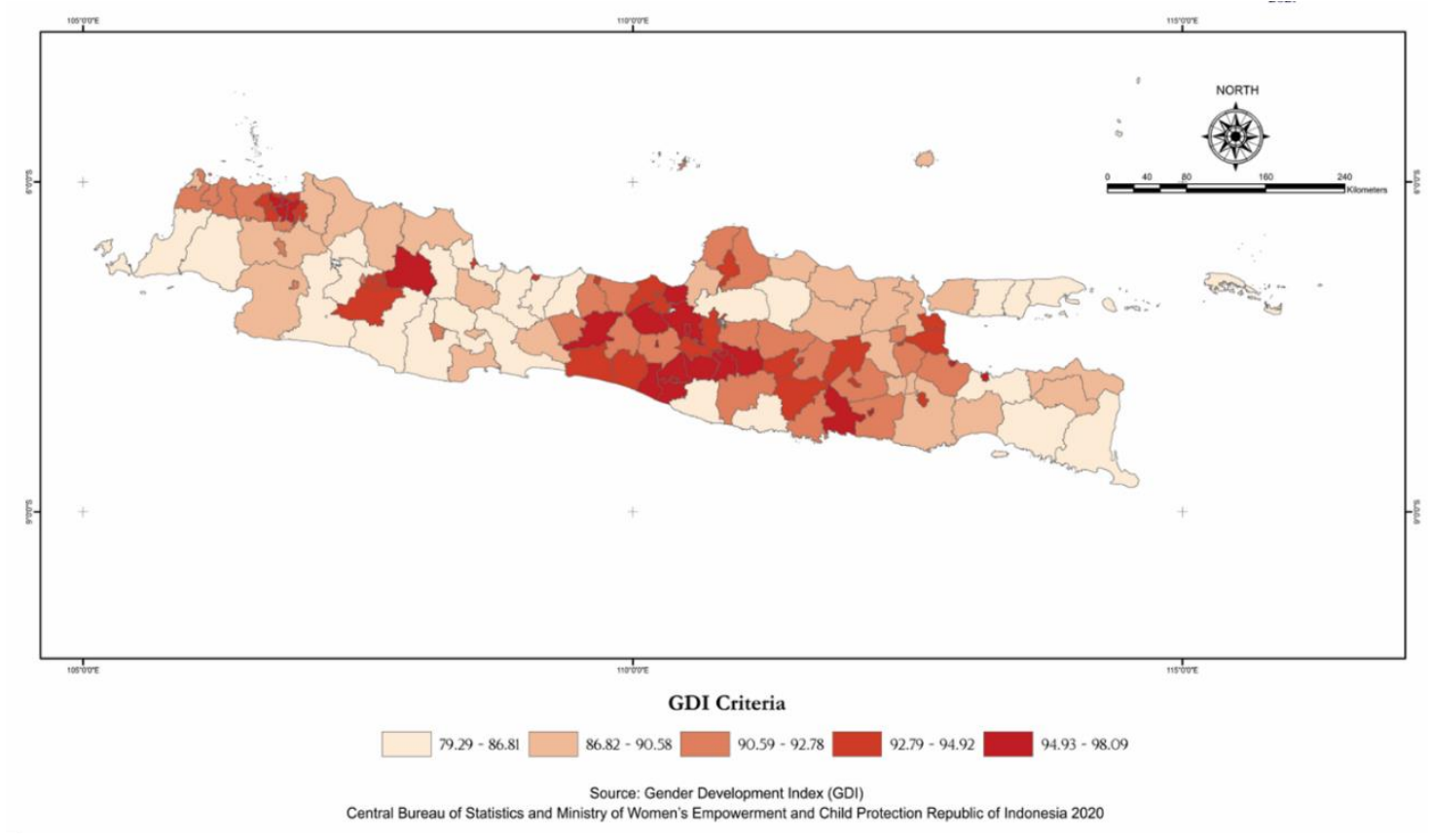




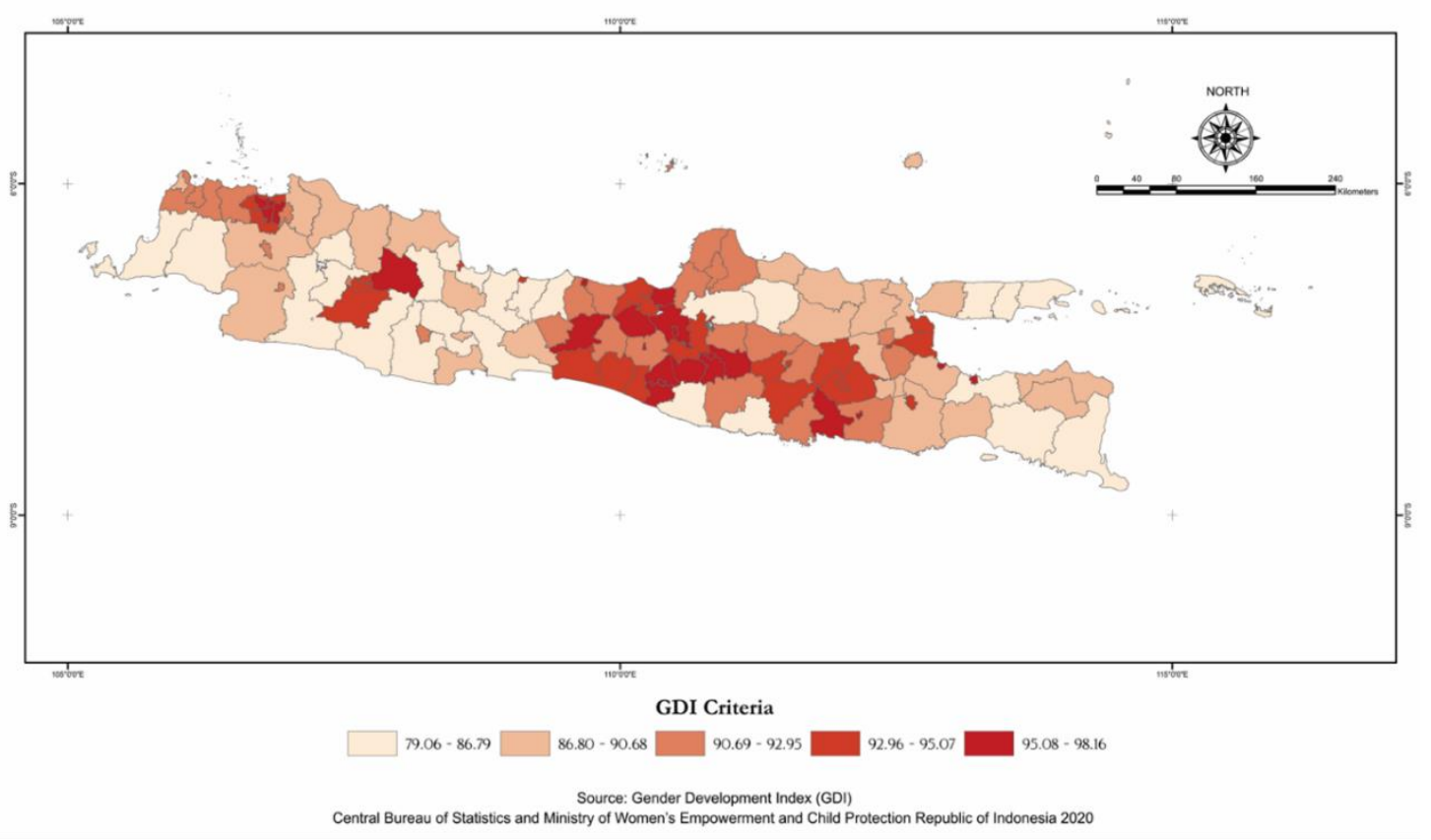

Figure 11. Spatial distribution of IPG in 2019 (top) and 2020 (bottom)

\section{Distribution Pattern}

Given the two z-score values in the 2019 and 2020 data do not meet the requirements, which are 1.379600 and 1.420996, respectively, the distribution pattern does not appear to be significantly different than random (Table 6). Furthermore, when viewed from the distribution of regencies/cities in quadrants, there are 38 and 36 regencies/cities respectively in 2019 and 2020 that are included in the $\mathrm{H}-\mathrm{H}$ quadrant spread across Banten, West Java and East Java.

As for the L-L quadrant, there are 11 and 10 regencies/cities in 2019 and 2020 spread across Banten, West Java, Central Java, and East Java (Figure 12). These clustered areas are Garut Regency, Ciamis Regency, Kuningan Regency, Majalengka Regency, Pangandaran Regency, Banjar City, Cilacap Regency and Brebes Regency. The cluster indicates that the border areas between West Java Province and Central
Java Province require increased gender development.

Areas that are included in the highlow cluster are only found in West Java Province, namely Bandung Regency, Sumedang Regency, Cirebon City, Tasikmalaya City; and Tegal City in Central Java Province. Areas in the high-low category have the potential to become the axis of gender development for surrounding areas that have a low GDI value. The existence of this development axis will later have implications for increasing gender development for the surrounding area. On the other hand, regencies/cities in low-high clusters tend to have low gender development but are surrounded or adjacent to areas that tend to have high gender development. Cooperation among regions with high and low GDI enables communication and exchange of experiences on how gender-based development mainstreaming is successfully implemented in a region.

Table 6. Global Moran I Values for the Distribution of IPG in 2019 and 2020

\begin{tabular}{llcc}
\hline No & & Data 2019 & Data 2020 \\
\hline 1 & Moran's Index & 0,113988 & 0,117657 \\
\hline 2 & Expected Index & $-0,008475$ & $-0,008475$ \\
\hline 3 & Variance & 0,007880 & 0,007879 \\
\hline
\end{tabular}




\begin{tabular}{llll}
\hline 4 & Z-Score & 1,379600 & 1,420996 \\
\hline 5 & P-Value & 0,167710 & 0,155318 \\
\hline
\end{tabular}

Source: Research results, 2021.
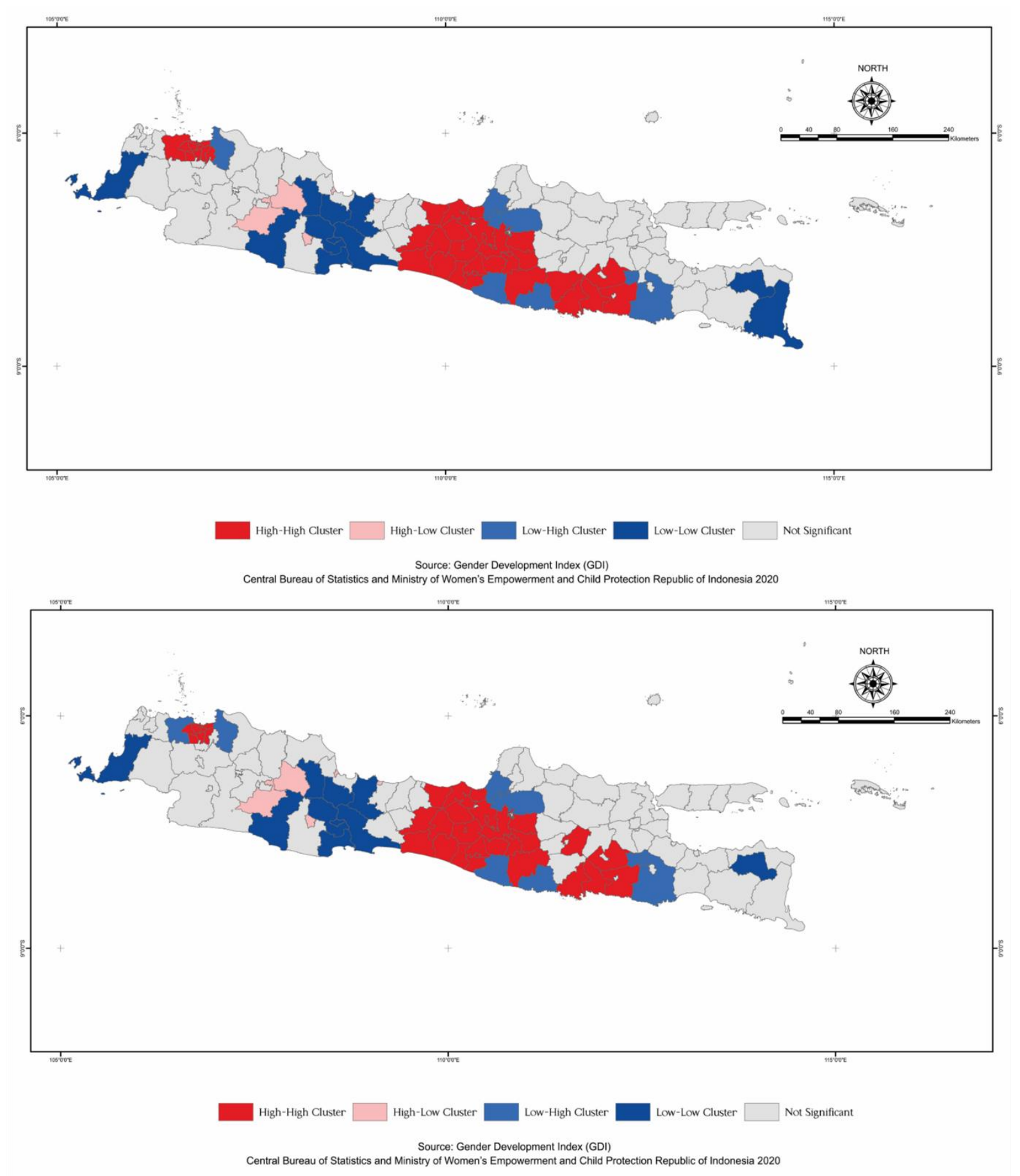

Figure 12. Distribution pattern of IPG in 2019 (top) and 2020 (bottom)

The results showed that regionalization which was carried out through spatial distribution mapping by making classes based on values and analysis of distribution patterns could make it easier to understand spatial phenomena. In this study, the main contemporary issues covering aspects of poverty, the COVID-19 pandemic, and gender are studied to provide an overview of the conditions of poverty, the COVID-19 pandemic, and the conditions of gender-based development in 
119 regencies/cities on the island of Java. The results of the analysis show that the distribution of the percentage of the poor and the poverty line in Java forms a clustered pattern. As for COVID-19 cases, the high concentration of cases is around DKI Jakarta and DI Yogyakarta. As for the gender aspect, there is a tendency for a scattered pattern on the value of the gender development index even though there are some areas with a tendency for high scores (H-H quadrant) and low scores (L-L quadrant).

\section{CONCLUSION}

The spatial distribution of clusters for the variable percentage of poor people and the poverty line in some regencies/cities in Java can be used as a basis for determining priorities for poverty alleviation efforts as well as reducing disparities among regions. Meanwhile, for aspects of the COVID-19 pandemic, the results of this study can be further utilized to see how the spatial distribution of COVID-19 cases is and how the possibility of COVID-19 transmission is affected by population mobility. As for the gender aspect, although the distribution pattern of the GDI does not appear to be significantly different than the random pattern, it can be used to determine which areas tend to have low and high GDI values. In general, the use of regional analysis can be used to see spatial phenomena, distributions and patterns formed, so that they can be used to determine appropriate policies or even to evaluate policies that are being implemented (Marinda, R.P. Sitorus, and Pribadi 2020). In addition, cooperation among regions that have the same characteristics is also possible to create development that is not only focused on one administrative area but in a region consisting of several regencies/cities.

\section{ACKNOWLEDGMENT}

Thank you to the Faculty of Geography, Universitas Gadjah Mada through the 2021 Laboratory Cluster Research Grant Funding which was given to the Regional Dynamics Laboratory.

\section{REFERENCES LIST}

Anselin, Luc. 1995. "Local Indicators of Spatial Association - LISA." Geographical Analysis 27(2):93-115. doi: 10.1111/j.1538-4632.1995.tb00338.x.

Arshad, Arlina. 2020. "Child Marriages on the Rise in Indonesia amid Covid-19 Outbreak."

Https:/Www.Straitstimes.Com/Asia/SeAsia/Child-Marriages-on-the-Rise-inIndonesia-amid-Covid-19-Outbreak, October 3.

Bayode, Taye, Ayobami Popoola, Olawale Akogun, Alexander Siegmund, Hangwelani Magidimisha-Chipungu, and Olusiyi Ipingbemi. 2022. "Spatial Variability of COVID-19 and Its Risk Factors in Nigeria: A Spatial Regression Method." Applied Geography 138:102621. doi: 10.1016/j.apgeog.2021.102621.

BPS. 2020a. "Penghitungan Dan Analisis Kemiskinan Makro Indonesia." 90.

BPS. 2020b. "Potret Sensus Penduduk 2020 Menuju Satu Data Kependudukan Indonesia." 1-20.

BPS. 2021. Statistik Indonesia 2021.

Brown, Lawrence A., and John Holmes. 1971. "The Delimitation of Functional Regions, Nodal Regions, and Hierarchies by Functional Distance Approaches." Journal of Regional Science 11(1):57-72. doi: 10.1111/j.1467-9787.1971.tb00240.x.

Burkhard, Benjamin, and Joachim Maes. 2017. Mapping Ecosystem Services. Advanced Books.

Cioban, Stefana, and Codruta Mare. 2021. "Spatial Clustering Behaviour of Covid-19 Conditioned by the Development Level: Case Study for the Administrative Units in Romania." Spatial Statistics 100558. doi: 10.1016/j.spasta.2021.100558.

Claval, Paul. 2006. "Regional Geography: Past and Present." 1-21.

Dini, Ikilah Muzayyanah, Fajriyah, Angraini Sylvianti, Fahmadia Eva, and Indah Lukitasari. 2020. Pembangunan Berbasis Gender. edited by I. M. Dini, Fajriyah, A. Sylvianti, and I. Lukitasari. Jakarta: 
Kementerian Pemberdayaan Perempuan dan Perlindungan Anak Republik Indonesia.

Djalante, Riyanti, Laely Nurhidayah, Hoang Van Minh, Nguyen Thi Ngoc Phuong, Yodi Mahendradhata, Angelo Trias, Jonatan Lassa, and Michelle Ann Miller. 2020. "COVID-19 and ASEAN Responses: Comparative Policy Analysis." Progress in Disaster Science 8:100129.

doi: 10.1016/j.pdisas.2020.100129.

Dubois, Laura. 2021. "The Impact of Solidarity Economy on Poverty: The Case of Public Centres of Solidarity Economy in Bahia, Brazil." World Development Perspectives 23. doi: 10.1016/j.wdp.2021.100343.

ESRI. 2021a. "Spatial Autocorrelation (Global Moran's I) (Spatial Statistics)." ArcGIS. (https://pro.arcgis.com/en/proapp/latest/tool-reference/spatialstatistics/spatialautocorrelation.htm).

ESRI. 2021b. "Spatial Statistics." ArcGIS. Retrieved (https:// pro.arcgis.com/en/proapp/latest/tool-reference/spatialstatistics/modeling-spatialrelationships.htm\#GUID-729B3B016911-41E9-AA99-8A4CF74EEE27).

Grekousis, George, Ruoyu Wang, and Ye Liu. 2021. "Mapping the Geodemographics of Racial, Economic, Health, and COVID-19 Deaths Inequalities in the Conterminous US." Applied Geography 135. doi: 10.1016/j.apgeog.2021.102558.

Gupta, Joyeeta, Maarten Bavinck, Mirjam Ros-Tonen, Kwabena Asubonteng, Hilmer Bosch, Edith van Ewijk, Michaela Hordijk, Yves van Leynseele, Mieke Lopes Cardozo, Esther Miedema, Nicky Pouw, Crelis Rammelt, Joeri Scholtens, Courtney Vegelin, and Hebe Verrest. 2021. "COVID-19, Poverty and Inclusive Development." World Development 145. doi: 10.1016/j.worlddev.2021.105527.
Healy, Stephen, Craig Borowiak, Marianna Pavlovskaya, and Maliha Safri. 2021. "Commoning and the Politics of Solidarity: Transformational Responses to Poverty." Geoforum 127:306-15. doi: 10.1016/j.geoforum.2018.03.015.

Jones, Nicola, Ingrid Sanchez Tapia, Sarah Baird, Silvia Guglielmi, Erin Oakley, Workneh Abebe Yadete, Maheen Sultan, and Kate Pincock. 2021. "Intersecting Barriers to Adolescents' Educational Access during COVID-19: Exploring the Role of Gender, Disability and Poverty." International Journal of Educational Development 85. doi: 10.1016/j.ijedudev.2021.102428.

Joshua, Vasna, J. Sylvia Grace, J. Godwin Emmanuel, S. Satish, and A. Elangovan. 2021. "Spatial Mapping of COVID-19 for Indian States Using Principal Component Analysis." Clinical Epidemiology and Global Health 10. doi: 10.1016/j.cegh.2020.100690.

Kuznetsov, Andrey, and Veronika Sadovskaya. 2021. "Spatial Variation and Hotspot Detection of COVID-19 Cases in Kazakhstan, 2020." Spatial and Spatio-Temporal Epidemiology 39. doi: 10.1016/j.sste.2021.100430.

van Lancker, Wim, and Zachary Parolin. 2020. "COVID-19, School Closures, and Child Poverty: A Social Crisis in the Making." The Lancet Public Health 5(5):e243-44. doi: 10.1016/S24682667(20)30084-0.

Lee, Jay, and David WS Wong. 2001. Statistical Analysis with ArcView GIS. New York: John Wiley \& Sons Inc.

Marinda, Ranti, Santun R.P. Sitorus, and Didit Okta Pribadi. 2020. "Analisis Pola Spasial Persebaran Kawasan Lahan Pertanian Pangan Berkelanjutan Di Kabupaten Karawang." Jurnal Geografi 12(02):161. doi: 10.24114/jg.v12i02.17646.

Martin, Amory, Maryia Markhvida, Stéphane Hallegatte, and Brian Walsh. 2020. "Socio-Economic Impacts of COVID-19 on Household Consumption and Poverty." Economics 
of Disasters and Climate Change. doi: 10.1007/s41885-020-00070-3.

Martinez-Beneito, Miguel A., Jorge Mateu, and Paloma Botella-Rocamora. 2021. "Spatio-Temporal Small Area Surveillance of the COVID-19 Pandemic." Spatial Statistics. doi: 10.1016/j.spasta.2021.100551.

Morais, Lucas Rabelo de Araújo, and Gecynalda Soares da Silva Gomes. 2021. "Applying Spatio-Temporal Scan Statistics and Spatial Autocorrelation Statistics to Identify COVID-19 Clusters in the World-a Vaccination Strategy?" Spatial and Spatio-Temporal Epidemiology 39. doi: 10.1016/j.sste.2021.100461.

Nathan, R. J., and T. A. McMahon. 1990. "Identification of Homogeneous Regions for the Purposes of Regionalisation." Journal of Hydrology 121(1-4):217-38. doi: 10.1016/00221694(90)90233-N.

Quereshy, Humzah A., Tarun K. Jella, Jeremy S. Ruthberg, Armine Kocharyan, Brian D'Anza, Nicole Maronian, and Todd D. Otteson. 2020. "'Hot Zones' for Otolaryngologists: Assessing the Geographic Distribution of Aerosol-Generating Procedures amidst the COVID-19 Pandemic." American Journal of Otolaryngology Head and Neck Medicine and Surgery $41(4)$.

doi: 10.1016/j.amjoto.2020.102550.

Rahiem, Maila D. H. 2021. "COVID-19 and the Surge of Child Marriages: A Phenomenon in Nusa Tenggara Barat, Indonesia." Child Abuse and Neglect 118. doi: 10.1016/j.chiabu.2021.105168.

Rahmawati, Anis, Layna Lutfiani, Zulvita Rahma Yunia, Isma'iddatur Rofiqoh, Fitri Fatimatuz Zahrok, and Destiana Wahyuningtyas. 2021. "Dampak Pandemic Covid- 19 Terhadap Indeks Pembangunan Ekonomi Inklusif Jawa Timur Indikator Tingkat Kemiskinan Dan Ketimpangan." Efektor 8(1):79-88. doi: 10.29407/e.v8i1.15708.

Rendana, Muhammad, Wan Mohd Razi Idris, and Sahibin Abdul Rahim. 2021.
"Spatial Distribution of COVID-19 Cases, Epidemic Spread Rate, Spatial Pattern, and Its Correlation with Meteorological Factors during the First to the Second Waves." Journal of Infection and Public Health 14(10):134048. doi: 10.1016/j.jiph.2021.07.010.

Riddel, R. 1985. “Regional Development Policy: The Struggle for Rural Progress in Low-Income Nations." P. 302 in regional development policy: the struggle for rural progress in low-income nations. Aldershot UK: Gower.

Rijanta, R., and M. Baiquni. 2020. Rembug Pageblug: Dampak, Respons Dan Konsekuensi Pandemi COVID-19 Dalam Dinamika Wilayah. Yogyakarta: Badan Penerbit Fakultas Geografi Universitas Gadjah Mada.

Seya, Hajime. 2020. "Global and Local Indicators of Spatial Associations." Spatial Analysis Using Big Data: Methods and Urban Applications 33-56. doi: 10.1016/B978-0-12-813127-5.00003-5.

Shadeed, Sameer, and Sandy Alawna. 2021. "GIS-Based COVID-19 Vulnerability Mapping in the West Bank, Palestine." International Journal of Disaster Risk Reduction $64 . \quad$ doi: 10.1016/j.ijdrr.2021.102483.

Sultan, Universitas, Ageng Tirtayasa, Lili Indriyani, and Sugeng Setyadi. 2021. Sugeng Setyadi (*) DAMPAK PANDEMI COVID-19 TERHADAP PENINGKATAN RESIKO KEMISKINAN DI INDONESIA. Vol. 4.

Sumaatmadja, Nursid. 1988. Studi Geografi: Suatu Pendekatan Dan Analisa Keruangan. Bandung: Alumni.

Suryahadi, Asep, Ridho Al Izzati, and Daniel Suryadarma. 2020. "Estimating the Impact of Covid-19 on Poverty in Indonesia*." Bulletin of Indonesian Economic Studies 1-34. doi: 10.1080/00074918.2020.1779390.

The Lancet. 2020. "Redefining Vulnerability in the Era of COVID-19." The Lancet 395(10230):1089. doi: 10.1016/S01406736(20)30757-1. 
UNDP. 2020. Human Development Report 2020. New: United Nations Development Programme.

Verma, Vijay, Achille Lemmi, Gianni Betti, Francesca Gagliardi, and Mario Piacentini. 2017. "Regional Science and Urban Economics How Precise Are Poverty Measures Estimated at the Regional Level? is." Regional Science and Urban Economics 66(June):175-84. doi: 10.1016/j.regsciurbeco.2017.06.007.

Wisner, Ben, J. C. Gaillard, and Ilan Kelman. 2012. "Framing Disaster: Theories and Stories Seeking to Understand Hazards , Vulnerability and Risk." Handbook of Hazards and Disaster Risk Reduction 18-33. doi: 10.4324/9781315689081. 